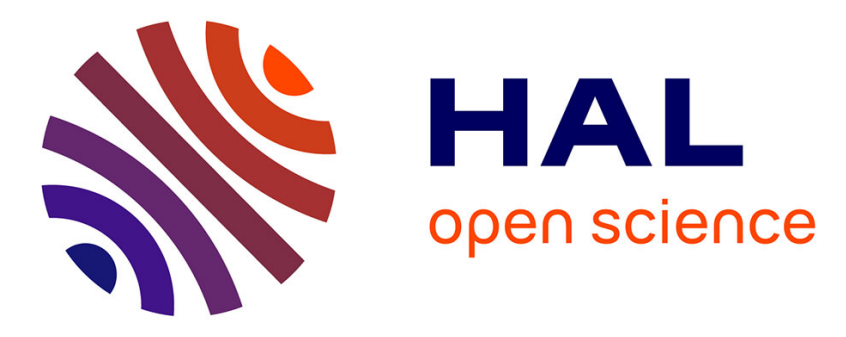

\title{
Cognitive workload across the spectrum of cognitive impairments: A systematic review of physiological measures
}

Maud Ranchet, John C. Morgan, Abiodun Emmanuel Akinwuntan, Hannes Devos

\section{To cite this version:}

Maud Ranchet, John C. Morgan, Abiodun Emmanuel Akinwuntan, Hannes Devos. Cognitive workload across the spectrum of cognitive impairments: A systematic review of physiological measures. Neuroscience and Biobehavioral Reviews, 2017, 80, pp.516-537. 10.1016/j.neubiorev.2017.07.001 . hal-01560604v2

\section{HAL Id: hal-01560604 https://hal.science/hal-01560604v2}

Submitted on 18 Aug 2017

HAL is a multi-disciplinary open access archive for the deposit and dissemination of scientific research documents, whether they are published or not. The documents may come from teaching and research institutions in France or abroad, or from public or private research centers.
L'archive ouverte pluridisciplinaire HAL, est destinée au dépôt et à la diffusion de documents scientifiques de niveau recherche, publiés ou non, émanant des établissements d'enseignement et de recherche français ou étrangers, des laboratoires publics ou privés. 
RANCHET, Maud, MORGAN, John C., AKINWUNTAN, Abiodun Emmanuel, DEVOS, Hannes, 2017, Cognitive workload across the spectrum of cognitive impairments: A systematic review of physiological measures, Neuroscience \& Biobehavioral Reviews, 80, pp. 516-537, DOI: 10.1016/j.neubiorev.2017.07.001

\section{This is a pre-print version of the manuscript}

Cognitive workload across the spectrum of cognitive impairments: A systematic review of physiological measures

Maud Ranchet, $\mathrm{PhD}^{1}$, John C. Morgan, MD, $\mathrm{PhD}^{2}$, Abiodun E. Akinwuntan, PhD, $\mathrm{MPH}, \mathrm{MBA}^{3}$, Hannes Devos, $\mathrm{PhD}^{4}$

1 Univ Lyon, IFSTTAR, TS2, LESCOT, F-69675, LYON, France

${ }^{2}$ Movement and Memory Disorder Programs, Department of Neurology, Medical College of Georgia, Augusta University, GA, USA

${ }^{3}$ Dean's office, School of Health Professions, The University of Kansas Medical Center, Kansas City, KS, USA

${ }^{4}$ Department of Physical Therapy and Rehabilitation Science, School of Health Professions, The University of Kansas Medical Center, Kansas City, KS, USA

\section{Corresponding author:}

Maud Ranchet, IFSTTAR, TS2-LESCOT, Bron, France.

Email: maud.ranchet@ifsttar.fr 


\section{ABSTRACT}

Our objective was to identify the physiological measures that are sensitive to assessing cognitive workload across the spectrum of cognitive impairments. Three database searches were conducted: PubMed, PsychINFO, and Web of Science. Studies from the last decade that used physiological measures of cognitive workload in older adults (mean age $>65$ years-old) were reviewed. The cognitive workload of healthy older individuals was compared with the cognitive workload of younger adults, patients with mild cognitive impairment $(\mathrm{MCl})$, and patients with Alzheimer's diseases (AD). The most common measures of cognitive workload included: electroencephalography, magnetoencephalography, functional magnetic resonance imaging, pupillometry, and heart rate variability. These physiological measures consistently showed greater cognitive workload in healthy older adults compared to younger adults when performing the same task. The same was observed in patients with $\mathrm{MCl}$ compared to healthy older adults. Behavioral performance declined when the available cognitive resources became insufficient to cope with the cognitive demands of a task, such as in AD. These findings may have implications for clinical practice and future cognitive interventions. 


\section{Introduction}

Cognitive workload is defined as the mental effort or the amount of attention allocated to perform a task (Kahneman, 1973). The concept of cognitive workload may be explained by a large number of theories including working memory, cognitive, or attentional theories (Baddeley, 1996; Kahneman, 1973; Sweller, 1994; Treisman, 1964). Central to these theories is the notion of limited resources. Based on the concept that our attentional capacity is limited, performance decreases when the task demands exceed the available capacity or when the available cognitive resources are allocated to other mental activities (Kahneman, 1973). In other words, when the cognitive workload required by the task is lower than the available cognitive resources, the task will be executed accurately. However, when the cognitive workload exceeds the available cognitive resources, the task performance will decrease. These cognitive resources may decrease due to physiological changes in cognitive functions as a result of healthy aging or dementia.

With fewer cognitive resources available to allocate to a task, older adults may show greater cognitive workload to perform equally well on a task as younger adults. This increased cognitive workload may be a predictor of future cognitive decline (Ahmadlou, Adeli, Bajo, \& Adeli, 2014; Aurtenetxe et al., 2013; F. C. Maestu, 2008). An anticipated silver tsunami, with older adults becoming the fastest growing segment of the population, will lead to an exponentially increasing number of individuals with cognitive impairments (Reitz, Brayne, \& Mayeux, 2011). Cognitive decline is believed to progress from a preclinical state to mild cognitive impairment $(\mathrm{MCl})$ and later to Alzheimer's disease $(A D)$, which is the most common type of dementia (Reitz et al., 2011). It is therefore paramount to find measures that could detect early cognitive decline in older adults, even before their manifestation in everyday behavior. Early detection of cognitive deficits may have implications for early clinical diagnosis, timely medical intervention, and early implementation of an effective rehabilitation protocol to stem the cognitive deterioration before cognitive symptoms emerge. Since cognitive deficits are associated with decreased quality of life (Lawson et al., 2014), early identification and management of cognitive deficits could lead to better quality of life for older adults. 
Different measures including subjective, behavioral, and physiological measures are available to assess cognitive workload. Subjective measures such as self-report ratings (e.g., NASA-Task Load Index) can be collected immediately after each task (Hart \& Staveland, 1988). However, this method of assessment may be problematic in terms of reliability since it depends on the perception of the individuals. Even when subjective rating scales are applied repeatedly within a task, it is unclear if the subjective methods provide a continuous measure of fluctuations in cognitive workload during task performance (Antonenko, Paas, Grabner, \& Gog, 2010). Behavioral measures such as performance from neuropsychological tests may be indirect measures of cognitive workload amount. Yet, similar to subjective measures, behavioral measures are not continuous. Physiological measures have the advantage to assess cognitive workload in-real time and can provide a continuous recording of data over time. Physiological measures may reflect early cognitive change which may appear before manifestation of symptoms in behavioral performances (Ahmadlou et al., 2014; Aurtenetxe et al., 2013; Bajo et al., 2010; Bokde et al., 2006; Chapman et al., 2007; Kochan et al., 2010; Leyhe et al., 2009; F. C. Maestu, 2008; Vannini et al., 2008).

Cognitive workload has been associated with a range of physiological measures. The most common physiological measures include electroencephalography (EEG) or magneto-encephalography (MEG), functional magnetic resonance imaging (fMRI), positron emission tomography (PET), measures from eye tracking or/and pupillometry (e.g. pupil size), cardiovascular measures (e.g. blood pressure), and electrodermal measures.

In this literature review, we will provide an overview of studies that used the most common physiological measures to assess cognitive workload across the spectrum of cognitive impairments, including normal healthy aging, $\mathrm{MCl}$, and $\mathrm{AD}$. We restricted our search to the last decade because the literature during this period in comparison to other decades showed increased use of technologies such as high resolution fMRI. In this review, we will therefore address 2 main questions: 1) What are the physiological measures sensitive to assessing cognitive workload in healthy aging? 2) What are the physiological measures sensitive to assessing cognitive workload in 
mild cognitive impairment and Alzheimer's disease?

Finally, we will address a number of remaining problems and point out directions for future research in this field.

\section{Methods}

\subsection{Data sources and searches}

This systematic review adhered to the PRISMA guidelines (Moher, Liberati, Tetzlaff, \& Altman, 2009). The four authors developed the search strategies with the assistance of an academic librarian. The literature search was performed using a combination of the keywords: cognitive workload, physiology, neurophysiology, cognitive science, electroencephalography, magnetoencephalography, functional magnetic resonance imagery, positron emission tomography, eye tracking, pupillometry, blood pressure, electrodermal measures, and their related search terms. The full list of search items can be found in our predefined protocol (available on request). Only articles written in English and published from January 1, 2006 to June 7, 2017, were included. Articles were searched in the following databases: PubMed, PsychINFO, and Web of Science. A hand search of the reference list of candidate articles was also performed.

\subsection{Study selection}

For the purpose of this review, all prospective or retrospective case series, comparative, case-control, cohort studies, and RCT's were selected on a number of eligibility criteria: (i) studies including at least one age group with an average age of 65 years old or older with or without $\mathrm{MCl}$ or Alzheimer's disease; (ii) studies including physiological measures in resting-state conditions associated with cognitive tests;

(iii) studies including physiological measures in real-time while participants performed a cognitive task. Case reports $(n<10)$, editorials, guidelines, letters, and reviews were excluded.

\subsection{Study and data extraction}

Titles and abstracts were scanned for relevance by M.R. The full texts of candidate 
articles were then appraised independently by H.D. and M.R. to confirm the eligibility. The two reviewers were not blinded to authors and study outcomes, because blinding has little effect on the outcome of systematic reviews. In case of disagreement, a third reviewer (J.C.M) made the final determination regarding eligibility. Data extractors collected information about population characteristics (number of adults, age, Mini Mental State Examination (MMSE) scores or Montreal Cognitive Assessment (MOCA) scores when available, task paradigm (type of task, number of conditions), main outcomes, and main results.

\section{Results}

The search process produced a total of 244 articles (electronically = 220; hand search $=24$ ) out of which only 40 were eligible for final inclusion in the review (Fig. 1). Tables 1 and 2 summarize the studies in healthy aging $(n=13)$ and studies in $\mathrm{MCl}$ and/or $\mathrm{AD}(\mathrm{n}=28)$. The 13 studies on healthy aging included 12 studies that used a cross-sectional design, and one study that used a cohort design. Of the 28 studies on $\mathrm{MCl}$ and/or AD, 26 used a cross-sectional design and two studies used a cohort design.

Studies included in the literature review will be discussed in two sections. The first section will identify the physiological measures sensitive to healthy aging. The second section will characterize the physiological measures sensitive to $\mathrm{MCl}$ and/or AD.

3.1. What are the physiological measures sensitive to assessing cognitive workload in healthy aging?

\subsubsection{Study that used physiological measures during resting state conditions}

a. $E E G$

EEG provides a direct measure of electrical activity produced by the brain via electrodes that are placed on the scalp. This technique, which measures changes in cognitive activity over time produces outputs with high temporal resolution. The rhythmic activity is divided into slow rhythm frequency bands (delta, theta, and alpha bands) and fast rhythms frequency bands (beta and gamma bands) (Volf \& Gluhih, 
2011). Based on the literature search, one study identified age-related changes in the resting state EEG power of the slow and fast rhythms recorded at different sites of the brain (Volf \& Gluhih, 2011). The objective of the study was to investigate whether the observed age-related changes reflected progressive compensatory rearrangements of cerebral activity during healthy aging. Their results showed that the fast rhythms (beta or gamma) increased when subjects' eyes were open in healthy older adults compared to younger adults. An increase in the power fast rhythms, specifically in beta bands, may reflect mobilization of larger resources. According to authors, this result supports the notion that a reorganization of cortical networks occurs due to age related physiological changes. This reorganization of cortical networks is essential for the involvement of compensatory mechanisms.

\subsubsection{Studies that used physiological measures while performing a cognitive task}

\section{a. $E E G$}

Older adults showed an increase in frontal midline theta power while performing a working memory task (face task) compared to younger adults based on EEG results (Gazzaley et al., 2008). The frontal midline theta power is localized at the medial prefrontal cortex. These findings suggest that older adults invested more overall effort in performing the task. Furthermore, the authors did not find significant differences in frontal midline theta power between relevant face stimuli and irrelevant scene stimuli in older adults, contrary to what they observed in younger adults. This result suggests that older adults exhibited difficulties with inhibition of irrelevant stimuli.

\section{b. $f M R I$}

Another technology that measures brain activity is fMRI. It detects changes in blood flow related to neural activity. This technique measures blood oxygenation level dependent (BOLD) signal and has the advantage to monitor brain activity with high spatial resolution.

Regardless of task difficulty, fMRI studies showed that older adults over-activated specific brain regions to achieve the same performance as younger adults while 
performing a working memory task (Cappell, Gmeindl, \& Reuter-Lorenz, 2010; Fischer et al., 2010). Compared to young adults, older adults showed an increase in brain activity in the right dorsolateral prefrontal cortex (especially the middle frontal gyrus sub-region) while performing a working memory task (Cappell et al., 2010). Similarly, older adults showed an increase in brain activity in the left temporo-parietal junction and left posterior cingulate gyrus compared to the younger group (under placebo conditions) while performing a spatial working memory task during an fMRI examination (Fischer et al., 2010). The dorsolateral prefrontal cortex, temporoparietal junction, and posterior cingulate gyrus have all been associated with working memory. The discrepancies in activation of different brain regions between the two studies might be explained by differences in task design (n-back task for Cappel et al., 2010; spatial delayed-matching task for Fischer et al., 2010). The over-activation of these brain regions might reflect the involvement of compensatory mechanisms due to age-related cognitive decline (Cappell et al., 2010; Fischer et al., 2010). Another fMRI study showed that older adults used a different pattern of brain activation compared to young adults while performing a cognitive interference task (Zhu, Zacks, \& Slade, 2010). Although both groups recruited functionally similar regions while performing the task, older adults had an activation pattern confined to smaller regions compared to younger adults with longer responses times to complete the task. Interestingly, older adults activated additional regions in the left frontal hemisphere (the left superior and medial frontal gyri) while performing the task (Zhu et al., 2010).

fMRI measures are not only sensitive to cognitive workload but also to task difficulty. With increasing task difficulty, fMRI studies also suggested that older adults had insufficient cognitive workload capacities and consequently showed decreased performances (Cappell et al., 2010; Fischer et al., 2010; Ginestet \& Simmons, 2011). Cappell et al. (2010) also showed that decreased performance of the working memory task was accompanied by decreased activation in regions of right dorsolateral prefrontal cortex in older adults compared to younger adults. Similarly, older adults showed an under-recruitment of fronto-parietal regions, especially in the 
left inferior frontal gyrus (Brodmann Area (BA) 9) and left inferior parietal lobule (BA 40) (Fischer et al., 2010). Furthermore, older adults had a decrease of connectivity strength as the task difficulty increased (Ginestet \& Simmons, 2011).

C. Functional near-infrared spectroscopy ( $f N I R S)$

The fNIRS technique is a type of functional neuroimaging technology that may be used to measure the occurrence of spontaneous slow oscillations of cerebral hemodynamics (Vermeij et al., 2014). The authors investigated the influence of age and cognitive workload on slow oscillations, using the n-back task. Results showed that healthy older adults exhibited decreased very-low-frequency oscillations in oxygenated and total haemoglobin compared to younger adults while performing a task that requires no working memory demand (control condition: 0-back) (Vermeij, Meel-van den Abeelen, Kessels, van Beek, \& Claassen, 2014). In the task that requires working memory demand (2-back condition), no significant differences between the two groups were observed. Contrary to younger adults, very-lowfrequency oscillations in healthy older adults did not reduce with increased cognitive workload. These findings suggest that very-low-frequency oscillations in oxygenated and total haemoglobin were not influenced by the cognitive workload in healthy older adults (Vermeij et al., 2014).

\section{d. PET}

One of the first imaging studies to investigate individual differences in cognitive workload used PET (Haier, 1993). This measure observes metabolic processes in the brain. Karlsson et al. (2009) investigated dopamine D1 receptor binding at rest and while performing a cognitive task in both younger and older adults. Whereas younger adults showed a reduction in binding receptor in three striatal compartments during the inhibition task compared to rest, no significant reduction in binding receptors was found in older adults. Findings provided evidence that the D1 system in older adults was less responsive to the cognitive workload required by the task when compared to younger adults (Karlsson et al., 2009).

\section{e. Pupillometry}


Task-evoked pupillary responses (TEPR) are successfully used to provide an estimate of the cognitive workload required to perform a task (Kahneman, 1973; Kahneman \& Beatty, 1966). Changes in pupil dilation, measured by an eye tracker were assessed as a direct measure of cognitive workload in two studies (Allard, Wadlinger, \& Isaacowitz, 2010; Piquado, Isaacowitz, \& Wingfield, 2010). Allard et al. (2010) used changes in pupil dilation to assess the level of cognitive workload required in older adults and younger adults while they viewed facial stimuli of varying emotions. Older adults had smaller changes in pupil dilation toward emotionalneutral face pairs than younger adults while performing the task. The authors argued that older adults possess a lower physiological sensitivity of the pupil to small changes in cognitive workload, when compared to younger adults. Similarly, another eye tracking study found that unadjusted pupil sizes of older adults were smaller than younger adults while listening and recalling digits or sentences (Piquado et al., 2010). However, when normalized for their more limited range, older adults had larger normalized pupil sizes compared to the younger adults during list acquisition and during the retention interval before recalling the list. This result suggests that older adults needed a greater effort than younger adults to reach their level of success. Dragan et al. (2017) examined the relationship between memory-guided visual search and pupillary responses in different groups of adults including one group of younger adults and one group of healthy older adults. Two memory tasks were administered in which participants had to detect the target in a visual scene. The authors analyzed visual search and pupillary responses, expressed as the change in pupil size, which is independent of absolute pupil size. Findings showed that older adults had worse memory-guided search and poorer pupillary responses than younger adults.

Like fMRI measures, TEPR are not only sensitive to cognitive workload of individuals but also to task difficulty in working memory. In this study, both younger and older adults' pupil size increased when the number of items to be remembered increased (Piquado et al., 2010). Although TEPR in younger and older adults were sensitive to an increase in digit lists in working memory, pupillary responses were not sensitive to 
the complexity of sentences in older adults (Piquado et al., 2010). This measure may be useful to determine the degree of difficulty required by the task but also to detect subtle cognitive deficits in healthy aging.

\section{f. Cardiovascular measures}

Cardiovascular measures such as heart rate, systolic blood pressure and diastolic blood pressure were found sensitive to cognitive effort (for review, see Gendolla \& Wright (2005)). Heart rate variability measured by an electrocardiogram is the analysis of beat-to-beat intervals. Blood pressure is usually measured by a finger blood pressure cuff. Among standard cardiovascular measures, systolic blood pressure was found to be the more reliable measure of cognitive workload (Gendolla \& Wright, 2005). Hess and Ennis (2012) used cardiovascular measures (heart rate, systolic blood pressure and diastolic blood pressure) as an indicator of cognitive workload and fatigue to assess the impact of aging on cognitive performance. Participants completed tasks with low (addition task) or high cognitive demands (subtraction task). Older adults showed greater changes in systolic blood pressure than younger adults at all levels of task difficulty (Hess \& Ennis, 2012).

These findings are in line with results from the same authors using changes in systolic and diastolic blood pressure to investigate differences in cognitive workload during a visual memory task (Ennis, Hess, \& Smith, 2013). These two last studies also revealed that changes in systolic blood pressure were sensitive to task difficulty. Older adults exhibited smaller changes in systolic blood pressure as difficulty increased, which was not the case for the younger adults (Ennis et al., 2013; Hess \& Ennis, 2012). These findings suggest that older adults had greater level of disengagement from the task than younger adults at higher levels of task difficulty (Ennis et al., 2013; Hess \& Ennis, 2012).

Using a blood pressure measure, older adults had higher levels of very-lowfrequency oscillations in blood pressure when the load level increased (2-back condition), compared to younger adults (Vermeij et al., 2014). However, these measures were not influenced by task difficulty in older adults, contrary to what the 
authors observed in younger adults. Older adults also showed a decrease in heart rate variability measures in the high-difficulty condition (hard trial) compared to the low-difficulty condition (easy trial), using an electrocardiograph (Mukherjee, 2011). Heart rate and certain heart rate variability measures were found to be reliable and sensitive tools in the evaluation of cognitive workload in older adults. In this study, there was no comparison group.

In general, older adults usually invested more overall effort than younger adults in performing an identical cognitive task.

3.2 What are the physiological measures sensitive to assessing cognitive workload in $\mathrm{MCl}$ and $A D$ ?

\subsubsection{Studies that used physiological measures during resting state conditions}

\section{a. $E E G / M E G$}

Alterations in the EEG/MEG rhythms in resting state conditions were associated with cognitive decline in patients with $\mathrm{MCl}$ and $\mathrm{AD}$ (Babiloni et al., 2015; Babiloni et al., 2006; Stam et al., 2006). Babiloni et al. (2006; 2015) investigated EEG measures during resting-state conditions in healthy older adults, patients with $\mathrm{MCl}$ and patients with AD. Findings showed that occipital delta sources and theta relative power increased and alpha 1 sources in the parietal, occipital temporal, and limbic cortices decreased with greater cognitive decline (Babiloni et al., 2006; Babiloni et al., 2015). Patients with $A D$ also showed reduced functional connectivity in delta and theta bands compared to healthy older adults although no significant between-group differences in source density in any of the frequency bands were found (Hata et al., 2016). Discrepancies between studies may be due to differences in the severity of cognitive decline. Correlation analyses showed that higher functional connectivity in the delta band reflected better performance in a test assessing global cognitive function (MMSE test).

In contrast to EEG, MEG is hardly affected by the skull, and does not require a reference electrode. A MEG study investigated the synchronization of brain regions, by measuring the functional connectivity in patients with AD compared to healthy 
older adults (Stam et al., 2006). Findings showed that functional connectivity was increased in patients with AD compared to healthy older adults locally in the theta (centro-parietal regions) as well as the beta and gamma bands (occipito-parietal regions) (Stam et al., 2006). The synchronization in alpha 1 and beta bands, especially involving interhemispheric temporal connections, were positively correlated to global cognition. The authors supported the relevance of using a simple resting-state condition for cognitive workload.

\section{b. $f M R I$}

The EEG/MEG results corroborate $\mathrm{fMRI}$ findings that showed distributed changes in brain connectivity in patients with $A D$ compared to healthy older adults, using the eigenvector centrality (EC) method (Binnewijzend et al., 2014). This analysis considered the brain as one large network rather than dividing it into several subnetworks. Patients with AD had greater changes in brain connectivity bilaterally in the medial frontal cortex, particularly the anterior cingulate and paracingulate gyrus compared to healthy older adults. These two regions are related to executive functions (Binnewijzend et al., 2014). These results indicated that frontal areas had a major role in the functional brain network in patients with AD. The authors discussed the possibility of a functional compensatory mechanism. However, contrary to healthy older adults, no significant correlations were found between changes in brain connectivity and MMSE scores in patients with AD (Binnewijzend et al., 2014).

\section{c. Pupillometry}

Using repetitive stimulation of the pupil light reflex, patients with $A D$ and patients with $\mathrm{MCl}$ showed less pronounced pupil size decrease and amplitude increase over time than controls (Bittner, Wieseler, Wilhelm, Riepe, \& Müller, 2014). Moreover, higher MMSE was associated with a higher increase of relative amplitude and greater decrease of latency in $\mathrm{AD}$ and $\mathrm{MCl}$, and absolute amplitude increase in $\mathrm{AD}$ alone. In other words, changes in pupil dynamics over time were less pronounced in AD and $\mathrm{MCl}$ and might reflect cognitive deficits. These authors showed that the use of repetitive stimulation of the pupil light reflex is better than initial pupil measurement 
(e.g pupil size) because it is independent of age-related physiological differences in pupil size.

3.2.2 Studies that used physiological measures while performing a cognitive task

a. $E E G / M E G$

Patients with $\mathrm{MCl}$ usually invested more overall effort than healthy older adults in performing an identical cognitive task. These results were found in EEG studies (Cummins et al., 2008) and MEG studies (Ahmadlou et al., 2014; Aurtenetxe et al., 2013; Bajo et al., 2010; Lopez et al., 2014; Maestu et al., 2008). Similarly, patients with $A D$ in the early stages needed greater effort than patients with $\mathrm{MCl}$ and healthy older adults to execute the task (Hidasi, Czigler, Salacz, Csibri, \& Molnár, 2007; van der Hiele et al., 2007; van Deursen, Vuurman, van Kranen-Mastenbroek, Verhey, \& Riedel, 2011; van Deursen, Vuurrman, Verhey, van kranen-Mastenbroek, \& Riedel, 2008). Changes in physiological measures and decreased task performances were observed as AD severity increased (Garn et al., 2015).

Using EEG measures, patients with amnestic MCI demonstrated lower EEG theta power around the frontal midline electrode compared to healthy older adults during a working memory task, which was associated with poorer performances in neuropsychological tests (Cummins, Broughton, \& Finnigan, 2008). The authors suggested that the reduced theta power observed around the frontal midline electrode reflected cognitive deficits in patients with $\mathrm{MCl}$. Using MEG measures, patients with $\mathrm{MCl}$ also showed bilateral higher activity in the ventral pathway (ventral prefrontal, middle temporal gyrus, medial temporal lobe) than healthy older adults during performance in a working memory task (Maestu et al., 2008). Similarly, Bajo et al. (2010) demonstrated an increase in posterior interhemispheric connectivity in the gamma band while patients with $\mathrm{MCl}$ performed a working memory task. To some extent, patients with $\mathrm{MCl}$ also showed an increase in functional connectivity in most of bands while performing a mental calculation task (Lopez et al., 2014). These changes were also associated with lower cognitive performance, which suggests that the increase in functional connectivity in most of bands was considered a compensatory mechanism for their cognitive decline. To be able to match the task 
performance of healthy older adults, patients with $\mathrm{MCl}$ showed modulated theta band power in frontal regions early and after stimulus onset (Aurtenetxe et al., 2013). The importance of theta band while performing a cognitive task was also highlighted in another MEG study (Ahmadlou et al., 2014). Indeed, the complexity of functional connectivity networks involved in the working memory task in patients with $\mathrm{MCl}$ was markedly reduced in the theta band of the whole brain and intra left hemisphere (Ahmadlou et al., 2014).

Studies showed that some EEG/MEG measures were not only sensitive to patients with $\mathrm{MCl}$ but also to the task difficulty (Cummins et al., 2008; Lopez et al., 2014). Only patients with $\mathrm{MCl}$ demonstrated significantly lower EEG theta power under high demand condition compared to low demand condition (Cummins et al., 2008). A similar pattern was observed in a MEG study (Lopez et al., 2014). When the task difficulty increased (e.g subtraction task), a decline in synchronization changes was noted only in patients with MCl (Lopez et al., 2014). These two last studies showed that patients with $\mathrm{MCl}$ have fewer cognitive resources available to meet the processing requirements of more demanding tasks (Cummins et al., 2008; Lopez et al., 2014).

Consistent with EEG/MEG findings in patients with $\mathrm{MCl}$, patients with $\mathrm{AD}$ in the early stages needed more effort to perform the cognitive task compared to healthy older adults (Beuzeron-Mangina \& Mangina, 2009; Hidasi et al., 2007; van der Hiele et al., 2007; van Deursen et al., 2011, 2008). Event-related potential components (ERPs) are measured by EEG. By using averaging techniques, ERPs extract specific sensory, cognitive or motor events. ERPs during a number-letter task were especially useful to detect patients with probable AD at an early stage (Chapman et al., 2007). Patients in very early stages of AD displayed abnormally high P450 amplitudes over parietal and occipital sites as opposed to healthy older individuals that may be explained by compensatory recruitment in parieto-occipital areas (Beuzeron-Mangina \& Mangina, 2009). Another EEG study analyzed the brain activity before and after the execution of a cognitive task (Hidasi et al., 2007). Following the completion of the cognitive task, the authors showed that the effect of 
the task on delta, alpha 2 and beta 1 frequencies was the opposite in patients with AD compared to healthy older individuals (Hidasi et al., 2007). The relative alpha 2 band power and alpha1 coherence differentiated AD patients from healthy older adults following completion of a cognitive task (Hidasi et al., 2007). The higher amount of relative alpha 2 band in patients with AD may correspond to a long-lasting effect of the increased effort invested in the execution of the task in patients with $A D$ or to a compensatory mechanism for their cognitive decline (Hidasi et al., 2007). Alpha 1 coherence was defined as the covariance of alpha activity at two electrode sites that can be used as an indicator of effective cortical connectivity (Hidasi et al., 2007). Unchanged alpha 1 coherence was also observed in the AD group, which may correspond to decrease in the level of functional connectivity of cortical areas recruited during the participation of the cognitive task. Alpha reactivity during memory tasks was decreased in patients with $A D$ compared to healthy older adults and related to performance on cognitive tests (van der Hiele et al., 2007).

Patients with $\mathrm{AD}$ also had an increase of the local gamma band power and higher early gamma band responses such as $40-\mathrm{Hz}$ steady state response power compared to patients with $\mathrm{MCl}$ and healthy older adults (van Deursen et al., 2011, 2008). Fast neural oscillations such as gamma bands were found to be an important mechanism for perceptual and cognitive processes (van Deursen et al., 2011; van Deursen et al., 2008). Increased local gamma band power in patients with AD could reflect a compensatory mechanism for alteration of long distance connectivity (van Deursen et al., 2008). Similarly, early gamma band responses might reflect a compensatory mechanism for their cognitive decline. These EEG measures, recorded during ongoing activity have been shown reproducible and able to differentiate patients with $A D$ from patients with $\mathrm{MCl}$ and healthy older adults. $A$ cohort study of qEEG measures found that theta power measured during facenaming encoding was closely related to AD severity (Garn et al., 2015).

b. $f M R I$

Consistent with EEG and MEG findings in patients with $\mathrm{MCl}$, an $\mathrm{fMRI}$ study showed changes in functional connectivity in patients with $\mathrm{MCl}$ while they engaged in a 
cognitive task with the same level of performance as healthy older adults (Bokde et al., 2006). These authors investigated changes in functional connectivity that may precede changes in brain activation in patients with $\mathrm{MCl}$ compared to healthy older adults (Bokde et al., 2006). Although no differences in task performances or brain activity were found between the two groups, results showed stronger correlation between the right middle fusiform gyrus and the left cuneus (parietal lobe) in patients with $\mathrm{MCl}$ compared to healthy older adults (Bokde et al., 2006). The authors suggested that the increase in functional connectivity could be the initial steps of a compensatory mechanism in patients with $\mathrm{MCl}$.

Another fMRI study showed that patients with $\mathrm{MCI}$ needed to activate additional regions while performing a spatial mental imagery task (e.g clock-specific tasks) to maintain the same level of performance as the healthy older adults (Leyhe et al., 2009). Patients with $\mathrm{MCl}$ also showed an over-activation in the right anterior cingulate and right precuneus compared to controls while performing a working memory task (Kochan et al., 2010). A longitudinal fMRI study (6 years of follow-up) showed that greater hippocampal activation during a memory task predicted a greater degree and rate of subsequent decline in patients with $\mathrm{MCI}$ (Miller et al., 2008). Consistent with these findings, patients with $\mathrm{MCl}$ with a MMSE score between 24 and 25 had stronger activity in specific regions (lingual gyrus, cuneus, and precuneus) than healthy older adults, despite similar performance in the spatial control task (Saur et al., 2010).

While previous studies showed similar behavioral performances while performing the task (Kochan et al., 2010; Leyhe et al., 2009; Saur et al., 2010), other studies revealed poorer behavioral performances between patients with $\mathrm{MCl}$ and healthy older adults using fMRI measures (Sole-Padulles et al., 2009), and PET measures (Gronholm, Rinne, Vorobyev, \& Laine, 2007). Discrepancies between the studies might be explained by differences in task design and patient characteristics. Higher cognitive reserve was associated with increased brain function in patients with $\mathrm{MCl}$ and $A D$, indicating that active compensatory mechanisms were still at work in patients with higher cognitive reserve (Sole-Padulles et al., 2009). 
fMRI measures were found to be also sensitive to task difficulty. Kochan et al. (2010) showed the effects of increments in working memory load on whole-brain patterns of activation and deactivation in patients with $\mathrm{MCl}$ compared to healthy older adults. Patients with $\mathrm{MCl}$ showed an under-activation (reduced activity) in the right anterior cingulate and right precuneus when the task increased in difficulty. In order to perform the high demand condition of the task, patients required more general cognitive resources leading to greater deactivation of default network in the posterior cingulate-medial precuneus compared to healthy older adults (Kochan et al., 2010). The authors suggested that the deactivation of specific regions could be a compensatory mechanism to overcome deficient functioning in other task-related regions. As observed in patients with $\mathrm{MCl}$, fMRI studies showed that patients with $A D$ in the mild stages had a higher activation in specific regions while performing a visuospatial task (Leyhe et al., 2009; Vannini et al., 2008). Compared with controls, patients with mild $A D$ showed an increase of activation in the right middle temporal gyrus while performing the task. This may indicate an attempt to compensate for dysfunctional areas in the dorsal visual pathway (Vannini et al., 2008). Similarly, the higher activation of the left precuneus in patients with mild AD during retrieval of clock time representations could reflect a compensatory mechanism of neurodegenerative processes (Leyhe et al., 2009). The authors argued that patients with $A D$ needed greater effort to complete the cognitive task than controls.

Similar to what we observed in patients with $\mathrm{MCl}$, patients with early $\mathrm{AD}$ who scored between 24 and 25 on the MMSE had higher activity in specific regions while performing a cognitive task (Saur et al., 2010). This result is consistent with another fMRI study that showed positive correlation between cognitive reserve and brain activity in patients with $A D$ whereas negative correlation between cognitive reserve and brain activity was observed in healthy older adults. In other words, patients with mild $A D$ recruited additional regions to support performance in the cognitive task. Findings suggested that active compensatory mechanisms were still at work among patients with mild AD (Sole-Padulles et al., 2009). Similar to EEG/MEG findings in patients with $A D$ regarding task difficulty, fMRI results of Vannini et al. (2008) found 
that patients with mild AD showed weaker or no BOLD signal in several areas of the dorsal visual pathway including bilateral precuneus, inferior parietal lobe and middle occipital gyrus, compared with controls (Vannini et al., 2008). This deactivation in several network regions could demonstrate the failure to modulate the neural response to increased task demand (Vannini et al., 2008).

C. PET

Consistent with EEG and $\mathrm{fMRI}$ findings, patients with $\mathrm{MCl}$ showed an increased activation in the anterior cingulate compared with the controls when naming newly learned objects, using PET measurements. This greater activation in the anterior cingulate was accompanied with poorer performances in learning the names of unfamiliar objects (Gronholm et al., 2007).

\section{d. Pupillometry}

Dragan et al. (2017) examined the relationship between memory-guided visual search and pupillary responses in patients with $\mathrm{MCl}$, patients with $\mathrm{AD}$, and healthy older adults, using two memory tasks. Findings showed that patients with probable early $A D$ had worse memory-guided search than healthy older adults. Patients with $A D$ exhibited decreased pupillary response compared to all other groups, with no difference between the response to novel and repeated trials in either task. These results suggest that the changes in pupil size might also reflect a deficit in memory in patients with AD.

\section{Discussion}

The objective of this review was to determine the physiological measures sensitive to assessing cognitive workload in healthy aging and age-related neurodegenerative diseases.

We identified six physiological measures of cognitive workload in this review: (1) EEG; (2) MEG; (3) fMRI; (4) PET; (5) pupillometry; and (6) cardiovascular measures. Any of the six physiological measures identified in our systematic review showed to be accurate in assessing cognitive workload in older adults and individuals with neurodegenerative diseases. Overall, studies showed that specific regions could 
serve as compensatory mechanisms that allow healthy older adults or patients with $\mathrm{MCl}$ or mild $\mathrm{AD}$ to achieve similar behavioral performances. However, when cognitive resources available were insufficient, (e.g patients with severe stages of $A D)$, there is a threshold where the brain can no longer compensate, which leads to a decline in behavioral performances.

These physiological measures consistently showed greater cognitive workload in healthy older adults compared to younger adults regardless of task difficulty. Increased theta power, over-activation of specific brain regions, increased functional connectivity, larger normalized pupil sizes, and greater changes in systolic blood pressure were indices of compensatory mechanisms in healthy age-related cognitive decline (Allard et al., 2010; Cappell et al., 2010; Ennis et al., 2013; Fischer et al., 2010; Gazzaley et al., 2008; Hess \& Ennis, 2012; Piquado et al., 2010). While healthy aging did not affect performance in the cognitive tasks in some studies (Cappell et al., 2010; Karlsson et al., 2009), others showed a decline in behavioral performances (Fischer et al., 2010; Piquado et al., 2010; Zhu et al., 2010), especially in situations of insufficient cognitive resources. This finding supports the notion of limited resources as a result of aging indicated by previous theories (Baddeley, 1996; Kahneman, 1973; Sweller, 1994; Treisman, 1964). Discrepancies between the results might be due to the nature of the task and the level of cognitive workload required by the task (Cappell et al., 2010). The pattern of these physiological measures was also modulated by task difficulty (Cappell et al., 2010; Ennis et al., 2013; Fischer et al., 2010; Hess \& Ennis, 2012; Piquado et al., 2010).

Abnormalities in physiological measures also occurred in older adults with $\mathrm{MCl}$ and AD even in resting state conditions (Babiloni et al., 2015, 2006; Bittner et al., 2014; Stam et al., 2006). $\mathrm{MCl}$ is recognized as a transitional state between healthy aging and dementia (Ahmadlou et al., 2014; Aurtenetxe et al., 2013; Bajo et al., 2010; Bittner et al., 2014; Bokde et al., 2006; Kochan et al., 2010; Leyhe et al., 2009; F. Maestu et al., 2008). Compared with healthy older adults, greater cognitive workload appeared in patients with $\mathrm{MCl}$, prior the manifestation of cognitive deficits in behavioral performances (Ahmadlou et al., 2014; Aurtenetxe et al., 2013; Bajo et al., 
2010; Bokde et al., 2006; Kochan et al., 2010; Leyhe et al., 2009; Maestu et al., 2008). These findings suggest that patients with $\mathrm{MCl}$ exhibited sufficient cognitive resources to compensate for their cognitive decline. Using EEG, MEG, or fMRI techniques, over-activation of specific brain regions and increased functional connectivity between different brain regions were used as compensatory mechanisms for the cognitive decline of patients with $\mathrm{MCl}$ (Bajo et al., 2010; Bokde et al., 2006; Gronholm et al., 2007; Kochan et al., 2010; Leyhe et al., 2009; Lopez et al., 2014; Maestu et al., 2008; Saur et al., 2010). When cognitive resources were insufficient, some studies showed that patients with $\mathrm{MCl}$ performed worse on behavioral tasks compared to healthy older adults (Sole-Padulles et al., 2009).

Although patients with AD allocated a high amount of cognitive resources to the cognitive task, these resources were insufficient to successfully execute the task. This may be reflected by reduced functional connectivity (Hata et al., 2016), decreased pupillary responses (Dragan et al., 2017) or alterations of pupil's light reflex (Bittner et al., 2014). Patients with AD showed greater cognitive workload accompanied with decreased behavioral performances during the cognitive task compared to older adults with $\mathrm{MCl}$ or healthy older adults (Leyhe et al., 2009; Saur et al., 2010; Sole-Padulles et al., 2009; van der Hiele et al., 2007; van Deursen et al., 2011; van Deursen et al., 2008). The higher amount of alpha 2 band after the task, the increased local gamma band power and early gamma band power, the higher P450 amplitudes over parietal and occipital sites, the over-activation or additional activation of specific regions in patients with $A D$ were used as compensatory mechanisms for their cognitive decline (Beuzeron-Mangina \& Mangina, 2009; Hidasi et al., 2007; Leyhe et al., 2009; Saur et al., 2010; Sole-Padulles et al., 2009; van Deursen et al., 2011, 2008).

Each physiological measure has strengths and weaknesses. In this review, a large number of studies ( $n=23$ ) used EEG or MEG to measure cognitive workload in healthy older adults, patients with $\mathrm{MCI}$ or $\mathrm{AD}$. These techniques may be used in resting state conditions and during cognitive tasks (Babiloni et al., 2015, 2006; Binnewijzend et al., 2014; Stam et al., 2006; Volf \& Gluhih, 2011). However, EEG 
has low spatial resolution and it is difficult to draw precise inference on the activated brain areas. EEG is also susceptible to motion artefacts, such as noise, blinking and movement. A variety of studies in older adults also used neuroimaging techniques such as fMRI. While this technique provides a good spatial resolution, fMRI studies are often too intrusive and difficult to apply in real-word activities that require high cognitive demand, such as driving. Only two studies explored PET measures (Gronholm et al., 2007; Karlsson et al., 2009). This could be explained by the fact that this technique is invasive and difficult to apply. Few studies were performed with cardiovascular measures or pupillometry. One of the reasons could be due to medication intake or physiological changes related to aging that limit the sensitivity of these techniques (Allard et al., 2010; Bittner et al., 2014; Dragan et al., 2017; Ennis et al., 2013; Hess \& Ennis, 2012). Contrary to fMRI or PET measures, cardiovascular and pupillary measures provide no clues about the locations of the underlying controlling neural systems. However, the limited intrusiveness of these measures allows for monitoring of cognitive workload during complex activities of daily life such as driving. Pupillary measures, such as TEPR, were found to be less intrusive than cardiovascular measures (Mukherjee, 2011).

This review has some limitations. It is possible that this review does not provide an exhaustive list of neurophysiological measures due to the focus on cognitive workload in aging and early dementia. However, this review emphasizes the need of future studies that compare the sensitivity of non-invasive neurophysiological measures of cognitive workload as early markers of cognitive decline. The fact that we only included group(s) of patients with a mean age above 65 years-old might explain the relatively few number of studies in $\mathrm{MCl}$ in our literature review. Most of the reviewed studies in patients with $\mathrm{MCl}$ or $\mathrm{AD}$ examined physiological measures while they are on medication. There was no information about the effect of medication and other comorbidities on these measures, which remains to be elucidated. In the reviewed studies, most of the tasks used while recording physiological measures showed a lack of extensive norms among younger and older adults, which makes difficult to generalize the results. In this review, we found a 
large heterogeneity in participant characteristics and task design. Indeed, age, number of participants, stage of severity, MOCA or MMSE scores varied between the studies as well as the nature of task and task difficulty. This could partly explain discrepancies between the results.

\subsection{Future research directions}

There are several important future areas of research made salient by the present review.

The literature demonstrated that physiological measures could detect early cognitive symptoms in older adults, even prior to the presence of cognitive deficits in behavioral performances. These findings have clinical implications in early and accurate diagnosis of dementia. The early detection of cognitive symptoms may also lead to the adequate monitoring of the disease progression and early intervention. Future research on the use of physiological measures in detecting and monitoring cognitive deficits should be considered.

One study in our literature review used a longitudinal approach (Miller et al., 2008). Longitudinal studies may be helpful in detecting intra-individual changes in brain activity, as inter-individual variation can have a masking effect (Mak et al., 2015). Contrary to performances in cognitive tasks, physiological measures are less affected by practice effects and are therefore helpful to detect discrete cognitive changes over time. The incorporation of physiological measures in longitudinal studies should be encouraged.

As discussed earlier, aging is associated with physiological measures that may limit the sensitivity of these measures. For these reasons, we recommend the use of measures that take into account physiological changes due to aging (e.g small pupil diameter in older adults). Future research should also continue the development of new indicators to accurately assess the cognitive workload.

\subsection{Implications}

The early detection of cognitive deficits may have implications in pharmaceutical and 
rehabilitation interventions. To date, pharmaceutical and rehabilitation interventions are initiated after significant changes in cognitive functions are observed (Connolly \& Lang, 2014; Van Vleet et al., 2016). Previous studies showed that cognitive function could be improved through cognitive rehabilitation interventions (Van Vleet et al., 2016). Although the benefits of these interventions have been proven in older adults (Van Vleet et al., 2016), their effectiveness may vary among individuals depending on their mental state at the moment of the training. The use of objective markers such as physiological measures for cognitive training could be a useful approach to monitor the participant's mental effort and engagement in the training. More research on cognitive training interventions should incorporate physiological markers. This would particularly be useful in a population of older adults in general, where a greater heterogeneity is observed.

\section{Conclusion}

We conclude that a great variety of physiological measures is available to detect cognitive workload in healthy aging, $\mathrm{MCl}$, and $\mathrm{AD}$. All physiological measures showed sensitivity in detecting changes in cognitive workload across the spectrum of cognitive impairment. Most of studies included in this review used techniques like EEG or MEG to measure cognitive workload. Future research should focus on a comparative analysis of the accuracy of physiological measures to detect and monitor early cognitive deficits in older adults. These findings may have implications for clinical practice and future cognitive interventions. 


\section{REFERENCES}

Ahmadlou, M., Adeli, A., Bajo, R., \& Adeli, H. (2014). Complexity of functional connectivity networks in mild cognitive impairment subjects during a working memory task. Clinical Neurophysiology, 125, 694-702. https://doi.org/10.1016/j.clinph.2013.08.033

Allard, E. S., Wadlinger, H. A., \& Isaacowitz, D. M. (2010). Positive gaze preferences in older adults: assessing the role of cognitive effort with pupil dilation. Neuropsychology, Development, and Cognition. Section B, Aging, Neuropsychology and Cognition, 17(3), 296-311. https://doi.org/10.1080/13825580903265681

Antonenko, P., Paas, F., Grabner, R., \& Gog, T. van. (2010). Using Electroencephalography to Measure Cognitive Load. Educational Psychology Review, 22(4), 425-438. https://doi.org/10.1007/s10648-010-9130-y

Aurtenetxe, S., Castellanos, N. P., Moratti, S., Bajo, R., Gil, P., Beitia, G., ... Maestú, F. (2013). Dysfunctional and compensatory duality in mild cognitive impairment during a continuous recognition memory task. International Journal of Psychophysiology, 87, 95-102. https://doi.org/http://dx.doi.org/10.1016/j.ijpsycho.2012.11.008

Babiloni, C., Binetti, G., Cassetta, E., Forno, G. D., Percio, C. D., Ferreri, F., ... Rossini, P. M. (2006). Sources of cortical rhythms change as a function of cognitive impairment in pathological aging: a multicenter study. Clinical Neurophysiology, 117, 252-268. https://doi.org/http://dx.doi.org/10.1016/j.clinph.2005.09.019

Babiloni, Del Percio, C., Boccardi, M., Lizio, R., Lopez, S., Carducci, F., ... Frisoni, G. B. (2015). Occipital sources of resting-state alpha rhythms are related to local gray matter density in subjects with amnesic mild cognitive impairment and Alzheimer's disease. Neurobiol Aging, 36, 556570. https://doi.org/10.1016/j.neurobiolaging.2014.09.011

Baddeley, A. D. (1996). Exploring the central executive. Quarter Journal Experimental Psychology, 5- 
28.

Bajo, R., Maestu, F., Nevado, A., Sancho, M., Gutierrez, R., Campo, P., ... Del-Pozo, F. (2010).

Functional connectivity in mild cognitive impairment during a memory task: implications for the disconnection hypothesis. J Alzheimers Dis, 22, 183-93. https://doi.org/10.3233/jad2010-100177

Beuzeron-Mangina, H., \& Mangina, C. A. (2009). Excessive compensatory recruitment as a compulsory neurophysiological mechanism in Very Early Alzheimer's Disease as compared to Mild Vascular Dementia and to age-matched normal controls. International Journal of Psychophysiology : Official Journal of the International Organization of Psychophysiology, 73(2), 164-169. https://doi.org/10.1016/j.ijpsycho.2009.03.007

Binnewijzend, M. A. A., Adriaanse, S. M., Van der Flier, W. M., Teunissen, C. E., de Munck, J. C., Stam, C. J., ... Wink, A. M. (2014). Brain network alterations in Alzheimer's disease measured by eigenvector centrality in $\mathrm{fMRI}$ are related to cognition and CSF biomarkers. Hum Brain Mapp, 35, 2383-2393. https://doi.org/10.1002/hbm.22335

Bittner, D. M., Wieseler, I., Wilhelm, H., Riepe, M. W., \& Müller, N. G. (2014). Repetitive pupil light reflex: potential marker in Alzheimer's disease? Journal of Alzheimer's Disease: JAD, 42(4), 1469-1477. https://doi.org/10.3233/JAD-140969

Bokde, A. L., Lopez-Bayo, P., Meindl, T., Pechler, S., Born, C., Faltraco, F., ... Hampel, H. (2006). Functional connectivity of the fusiform gyrus during a face-matching task in subjects with mild cognitive impairment. Brain, 129, 1113-24. https://doi.org/10.1093/brain/awl051

Cappell, K. A., Gmeindl, L., \& Reuter-Lorenz, P. A. (2010). Age differences in prefontal recruitment during verbal working memory maintenance depend on memory load. Cortex, 46, 462-73. https://doi.org/10.1016/j.cortex.2009.11.009

Chapman, R. M., Nowlis, G. H., McCrary, J. W., Chapman, J. A., Sandoval, T. C., Guillily, M. D., ... 
Reilly, L. A. (2007). Brain event-related potentials: Diagnosing early-stage Alzheimer's disease. Neurobiol Aging, 28, 194-201.

https://doi.org/10.1016/j.neurobiolaging.2005.12.008

Connolly, B. S., \& Lang, A. E. (2014). Pharmacological treatment of Parkinson disease: a review. JAMA, 311(16), 1670-1683. https://doi.org/10.1001/jama.2014.3654

Cummins, T. D., Broughton, M., \& Finnigan, S. (2008). Theta oscillations are affected by amnestic mild cognitive impairment and cognitive load. Int J Psychophysiol, 70, 75-81. https://doi.org/10.1016/j.ijpsycho.2008.06.002

Dragan, M. C., Leonard, T. K., Lozano, A. M., McAndrews, M. P., Ng, K., Ryan, J. D., ... Hoffman, K. L. (2017). Pupillary responses and memory-guided visual search reveal age-related and Alzheimer's-related memory decline. Behavioural Brain Research, 322(Pt B), 351-361. https://doi.org/10.1016/j.bbr.2016.09.014

Ennis, G. E., Hess, T. M., \& Smith, B. T. (2013). The impact of age and motivation on cognitive effort: implications for cognitive engagement in older adulthood. Psychol Aging, 28, 495-504. https://doi.org/10.1037/a0031255

Fischer, H., Nyberg, L., Karlsson, S., Karlsson, P., Brehmer, Y., Rieckmann, A., ... Backman, L. (2010). Simulating neurocognitive aging: effects of a dopaminergic antagonist on brain activity during working memory. Biological Psychiatry, 67(6), 575-580.

https://doi.org/10.1016/j.biopsych.2009.12.013

Garn, H., Waser, M., Deistler, M., Benke, T., Dal-Bianco, P., Ransmayr, G., ... Schmidt, R. (2015). Quantitative EEG markers relate to Alzheimer's disease severity in the Prospective Dementia Registry Austria (PRODEM). Clinical Neurophysiology, 126, 505-513. https://doi.org/10.1016/j.clinph.2014.07.005

Gazzaley, A., Clapp, W., Kelley, J., McEvoy, K., Knight, R. T., \& D’Esposito, M. (2008). Age-related top- 
down suppression deficit in the early stages of cortical visual memory processing. PNAS Proceedings of the National Academy of Sciences of the United States of America, 105, 13122-13126. https://doi.org/10.1073/pnas.0806074105

Gendolla, G. H. E., \& Wright, R. A. (2005). Motivation in social settings: Studies of effort-related cardiovascular arousal. In J. P. Forgas, K. Williams, \& B. von Hippel (Eds.), Social motivation: Conscious and nonconscious processes. Cambridge University Press.

Ginestet, C. E., \& Simmons, A. (2011). Statistical parametric network analysis of functional connectivity dynamics during a working memory task. Neurolmage, 55(2), 688-704. https://doi.org/10.1016/j.neuroimage.2010.11.030

Gronholm, P., Rinne, J. O., Vorobyev, V. A., \& Laine, M. (2007). Neural correlates of naming newly learned objects in $\mathrm{MCl}$. Neuropsychologia, 45, 2355-68. https://doi.org/10.1016/j.neuropsychologia.2007.02.003

Haier, R. J. (1993). Cerebral glucose metabolism and intelligence. In Biological approaches to the study human intelligence (pp. 317-332). Norwoord, NJ: Ablex.

Hart, S. G., \& Staveland, L. E. (1988). Development of NASA-TLX (Task Load Index): Results of Empirical and Theoretical Research. Advances in Psychology, 52, 139-183. https://doi.org/10.1016/S0166-4115(08)62386-9

Hata, M., Kazui, H., Tanaka, T., Ishii, R., Canuet, L., Pascual-Marqui, R. D., ... Takeda, M. (2016). Functional connectivity assessed by resting state EEG correlates with cognitive decline of Alzheimer's disease - An eLORETA study. Clinical Neurophysiology: Official Journal of the International Federation of Clinical Neurophysiology, 127(2), 1269-1278. https://doi.org/10.1016/j.clinph.2015.10.030

Hess, T. M., \& Ennis, G. E. (2012). Age differences in the effort and costs associated with cognitive activity. J Gerontol B Psychol Sci Soc Sci, 67, 447-55. https://doi.org/10.1093/geronb/gbr129 
Hidasi, Z., Czigler, B., Salacz, P., Csibri, É., \& Molnár, M. (2007). Changes of EEG spectra and coherence following performance in a cognitive task in Alzheimer's disease. International Journal of Psychophysiology, 65, 252-260.

https://doi.org/http://dx.doi.org/10.1016/j.ijpsycho.2007.05.002

Kahneman, D. (1973). Attention and Effort. Englewood Cliffs, NJ: Prentice-Hall.

Kahneman, D., \& Beatty, J. (1966). Pupil diameter and load on memory. Science, 154, 1583-5.

Karlsson, S., Nyberg, L., Karlsson, P., Fischer, H., Thilers, P., Macdonald, S., ... Backman, L. (2009). Modulation of striatal dopamine D1 binding by cognitive processing. Neurolmage, 48(2), 398-404. https://doi.org/10.1016/j.neuroimage.2009.06.030

Kochan, N. A., Breakspear, M., Slavin, M. J., Valenzuela, M., McCraw, S., Brodaty, H., \& Sachdev, P. S. (2010). Functional alterations in brain activation and deactivation in mild cognitive impairment in response to a graded working memory challenge. Dement Geriatr Cogn Disord, 30, 553-68. https://doi.org/10.1159/000322112

Lawson, R. A., Yarnall, A. J., Duncan, G. W., Khoo, T. K., Breen, D. P., Barker, R. A., ... Burn, D. J. (2014). Severity of mild cognitive impairment in early Parkinson's disease contributes to poorer quality of life. Parkinsonism \& Related Disorders, 20, 1071-5. https://doi.org/10.1016/j.parkreldis.2014.07.004

Leyhe, T., Erb, M., Milian, M., Eschweiler, G. W., Ethofer, T., Grodd, W., \& Saur, R. (2009). Changes in cortical activation during retrieval of clock time representations in patients with mild cognitive impairment and early Alzheimer's disease. Dement Geriatr Cogn Disord, 27, 11732. https://doi.org/10.1159/000197930

Lopez, M. E., Garces, P., Cuesta, P., Castellanos, N. P., Aurtenetxe, S., Bajo, R., ... Maestu, F. (2014). Synchronization during an internally directed cognitive state in healthy aging and mild cognitive impairment: a MEG study. Age, 36, 1389-1406. https://doi.org/10.1007/s11357- 
014-9643-2

Maestu, F. C. (2008). Increased biomagnetic activity in the ventral pathway in mild cognitive impairment. Clinical Neurophysiology, 119, 1320-1327. https://doi.org/10.1016/j.clinph.2008.01.105

Maestu, F., Campo, P., Del Rio, D., Moratti, S., Gil-Gregorio, P., Fernandez, A., ... Ortiz, T. (2008). Increased biomagnetic activity in the ventral pathway in mild cognitive impairment. Clinical Neurophysiology, 119, 1320-1327. https://doi.org/10.1016/j.clinph.2008.01.105

Mak, E., Su, L., Williams, G. B., Firbank, M. J., Lawson, R. A., Yarnall, A. J., ... O’Brien, J. T. (2015). Baseline and longitudinal grey matter changes in newly diagnosed Parkinson's disease: ICICLE-PD study. Brain: A Journal of Neurology, 138(Pt 10), 2974-2986. https://doi.org/10.1093/brain/awv211

Miller, S. L., Fenstermacher, E., Bates, J., Blacker, D., Sperling, R. A., \& Dickerson, B. C. (2008). Hippocampal activation in adults with mild cognitive impairment predicts subsequent cognitive decline. J Neurol Neurosurg Psychiatry, 79, 630-5. https://doi.org/10.1136/jnnp.2007.124149

Moher, D., Liberati, A., Tetzlaff, J., \& Altman, D. G. (2009). Preferred reporting items for systematic reviews and meta-analyses: the PRISMA statement. Bmj, 339, b2535. https://doi.org/10.1136/bmj.b2535

Mukherjee, S. Y. (2011). Sensitivity to mental effort and test-retest reliability of heart rate variability measures in healthy seniors. Clinical Neurophysiology, 122, 2059-2066. https://doi.org/10.1016/j.clinph.2011.02.032

Piquado, T., Isaacowitz, D., \& Wingfield, A. (2010). Pupillometry as a measure of cognitive effort in younger and older adults. Psychophysiology, 47(3), 560-569. https://doi.org/10.1111/j.1469-8986.2009.00947.x 
Reitz, C., Brayne, C., \& Mayeux, R. (2011). Epidemiology of Alzheimer disease. Nature Reviews. Neurology, 7(3), 137-152. https://doi.org/10.1038/nrneurol.2011.2

Saur, R., Milian, M., Erb, M., Eschweiler, G. W., Grodd, W., \& Leyhe, T. (2010). Cortical activation during clock reading as a quadratic function of dementia state. J Alzheimers Dis, 22, 267-84. https://doi.org/10.3233/jad-2010-091390

Sole-Padulles, C., Bartres-Faz, D., Junque, C., Vendrell, P., Rami, L., Clemente, I. C., ... Molinuevo, J. L. (2009). Brain structure and function related to cognitive reserve variables in normal aging, mild cognitive impairment and Alzheimer's disease. Neurobiol Aging, 30, 1114-24. https://doi.org/10.1016/j.neurobiolaging.2007.10.008

Stam, C. J., Jones, B. F., Manshanden, I., van Cappellen van Walsum, A. M., Montez, T., Verbunt, J. P. A., ... Scheltens, P. (2006). Magnetoencephalographic evaluation of resting-state functional connectivity in Alzheimer's disease. Neuroimage, 32, 1335-1344. https://doi.org/http://dx.doi.org/10.1016/j.neuroimage.2006.05.033

Sweller, J. (1994). Cognitive load theory, learning difficulty, and instructional design. Learning and Instruction, 4, 295-312. https://doi.org/http://dx.doi.org/10.1016/0959-4752(94)90003-5 Treisman, a. m. (1964). Selective attention in man. Br. Med. Bull., 20, 12-16. van der Hiele, K., Vein, A. A., Reijntjes, R. H. A. M., Westendorp, R. G. J., Bollen, E. L. E. M., van Buchem, M. A., ... Middelkoop, H. A. M. (2007). EEG correlates in the spectrum of cognitive decline. Clinical Neurophysiology, 118, 1931-1939. https://doi.org/http://dx.doi.org/10.1016/j.clinph.2007.05.070 van Deursen, J. A., Vuurman, E., van Kranen-Mastenbroek, V., Verhey, F. R. J., \& Riedel, W. J. (2011). 40-Hz steady state response in Alzheimer's disease and mild cognitive impairment. Neurobiol Aging, 32, 24-30. https://doi.org/10.1016/j.neurobiolaging.2009.01.002 van Deursen, J. A., Vuurrman, E. F. P. M., Verhey, F. R. J., van kranen-Mastenbroek, V. H. J. M., \& 
Riedel, W. J. (2008). Increased EEG gamma band activity in Alzheimer's disease and mild cognitive impairment. J Neural Transm, 115, 1301-1311.

Van Vleet, T. M., DeGutis, J. M., Merzenich, M. M., Simpson, G. V., Zomet, A., \& Dabit, S. (2016). Targeting alertness to improve cognition in older adults: A preliminary report of benefits in executive function and skill acquisition. Cortex, 82, 100-118. https://doi.org/10.1016/j.cortex.2016.05.015

Vannini, P., Lehmann, C., Dierks, T., Jann, K., Viitanen, M., Wahlund, L.-O., \& Almkvist, O. (2008). Failure to modulate neural response to increased task demand in mild Alzheimer's disease: fMRI study of visuospatial processing. Neurobiology of Disease, 31, 287-297. https://doi.org/http://dx.doi.org/10.1016/j.nbd.2008.04.013

Vermeij, A., Meel-van den Abeelen, A. S. S., Kessels, R. P. C., van Beek, A. H. E. A., \& Claassen, J. A. H. R. (2014). Very-low-frequency oscillations of cerebral hemodynamics and blood pressure are affected by aging and cognitive load. Neurolmage, 85 Pt 1, 608-615. https://doi.org/10.1016/j.neuroimage.2013.04.107

Volf, N. V., \& Gluhih, A. A. (2011). Background cerebral electrical activity in healthy mental aging. Human Physiology, 37, 559-567. https://doi.org/10.1134/\$0362119711040207

Zhu, D. C., Zacks, R. T., \& Slade, J. M. (2010). Brain activation during interference resolution in young and older adults: an fMRI study. Neurolmage, 50(2), 810-817. https://doi.org/10.1016/j.neuroimage.2009.12.087 


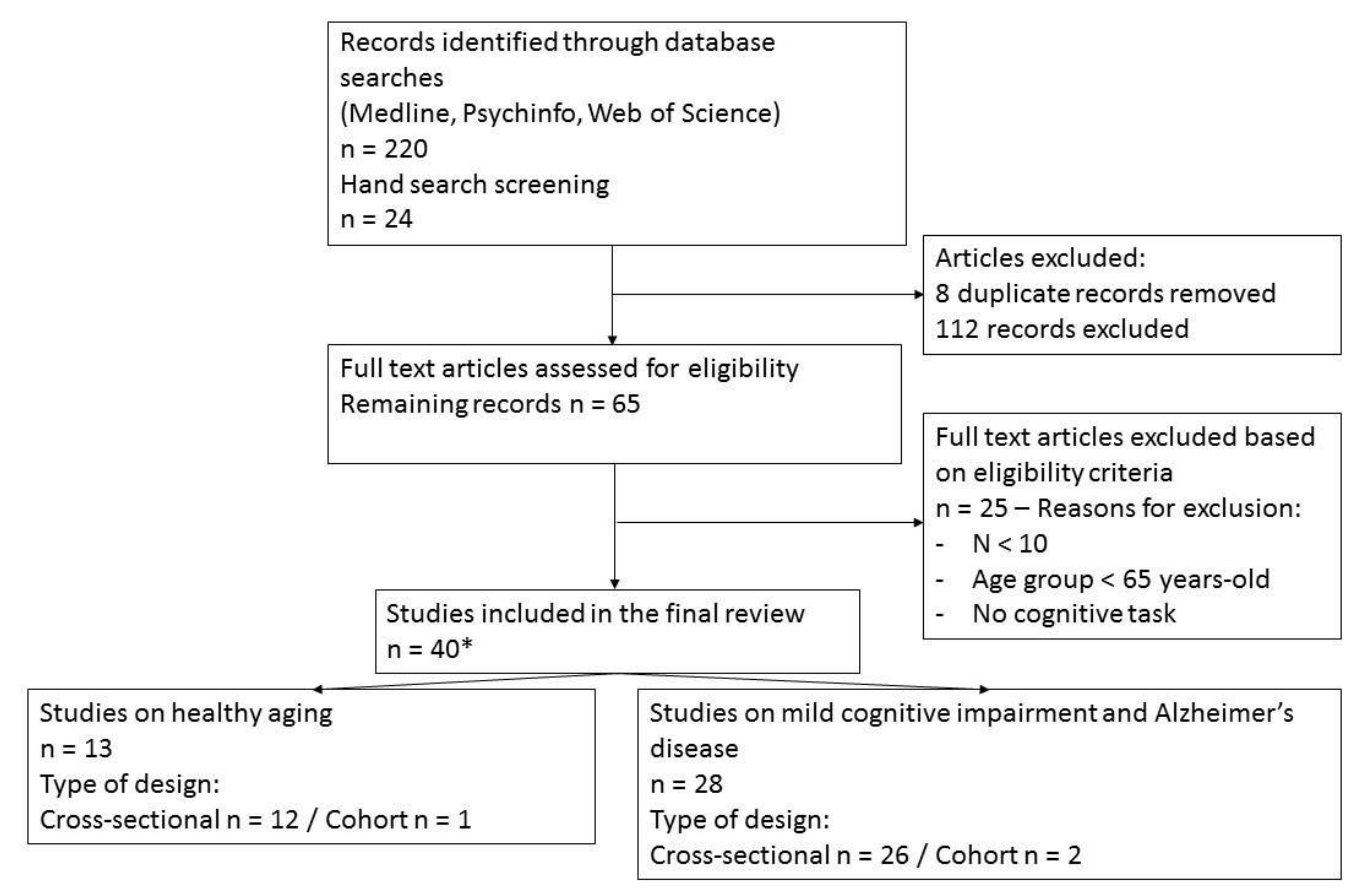

Fig.1. Flow diagram of the screening process of the included articles

*Among 40 studies, one study (Dragan et al., 2017) has been described in the two sections 
Table 1. Studies that used physiological measures in healthy aging

\begin{tabular}{|c|c|c|c|c|c|}
\hline References & $\begin{array}{l}\text { Population } \\
\text { characteristics }\end{array}$ & Task paradigm & Main outcomes & Main results & $\begin{array}{l}\text { Between-group } \\
\text { or within group } \\
\text { comparisons }^{1}\end{array}$ \\
\hline
\end{tabular}

In resting state

conditions

EEG measures

Volf et al. (2011)

32 older adults,

age \pm SD: $65.1 \pm$

2 conditions: eyes

closed or open

$1.2 ; 33$ younger

adults, age \pm SD:

$22.1 \pm 0.4$
Behavioral data: $I Q$,
originality of drawings

in the Torrance test;

EEG data: EEG power of

the bands

delta, theta 1 , theta 2 ,

alpha 1 , alpha 2 , beta 1 ,

beta 2 , gamma 1 , and

gamma 2 bands

$\begin{array}{ll}\text { Behavioral data: IQ } & Y>0 \\ \text { Originality of drawings in the Torrance test } & Y=0\end{array}$

EEG data:

The mean power of the slow rhythms (delta,

theta, and alpha 2) in the eyes-closed condition: $\quad Y>0$

The mean power of the fast beta and gamma

rhythms in eyes-open condition $\quad \mathrm{Y}<0$

While performing

a cognitive task

EEG measures

Gazzaley et al.

(2008)

26 older adults, age (range): 65.7

(60-72); 20

younger adults,

age (range): 23.1

(19-30)

Working memory

task with 3

conditions: 1 . face

task: remember

faces and ignore

scenes 2. scene

task: remember

scenes and ignore
Behavioral data:

recognition accuracy,

RT for face and scene

WM tasks;

Frontal EEG measures: EEG data:

frontal midline theta Theta power for face stimuli

Behavioral data for both face and scene tasks:
Theta power in younger participants:

relevant stimuli > irrelevant stimuli; in older

Accuracy

RT

$\mathrm{Y}>\mathrm{O}$

$Y=O$

$\mathrm{Y}<\mathrm{O}$ 


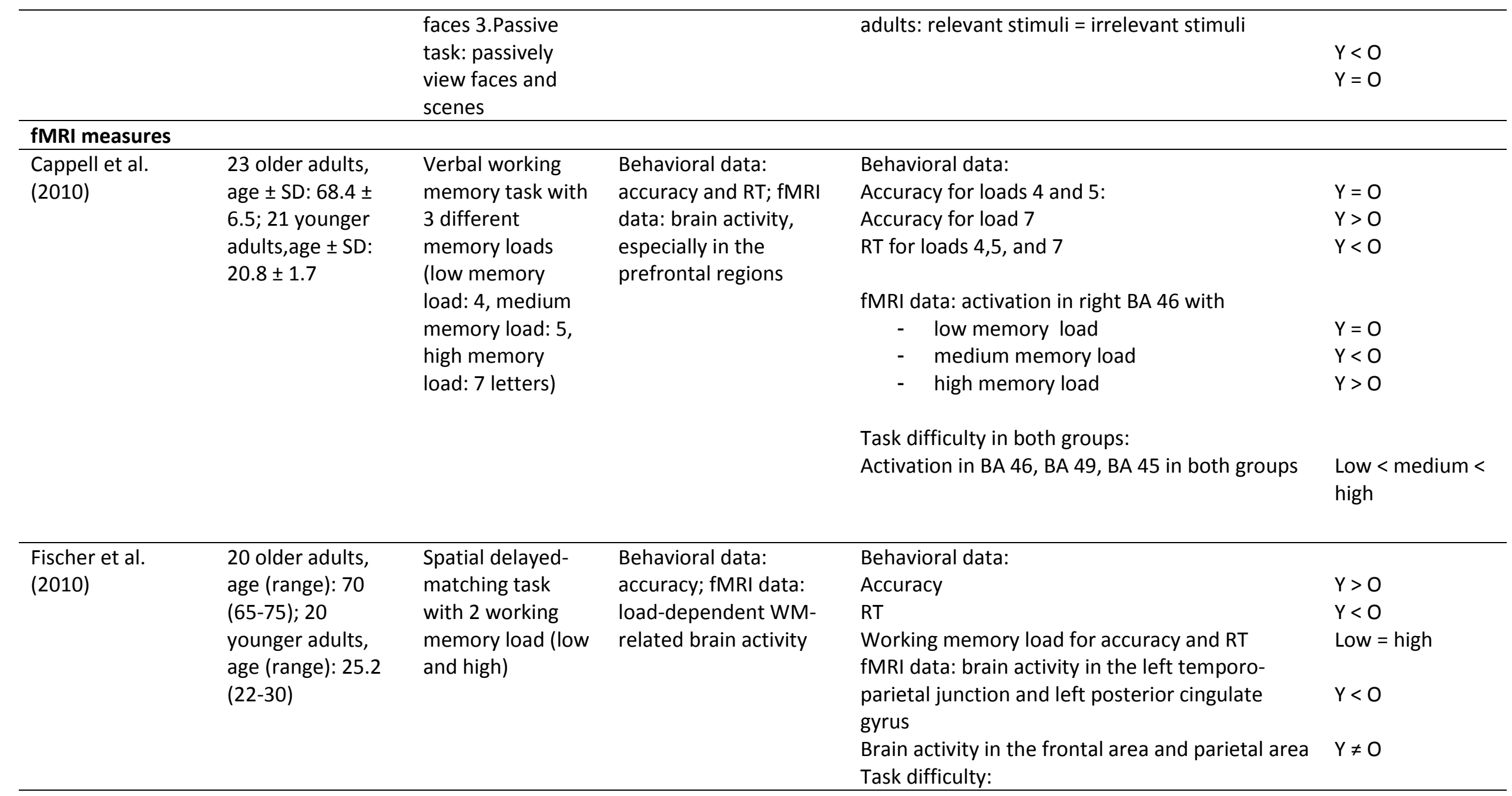




\begin{tabular}{|c|c|c|c|c|c|}
\hline & & & & $\begin{array}{l}\text { fMRI data: brain activity in the fronto-parietal } \\
\text { regions in: } \\
\begin{aligned} \text { - } & \text { younger adults (under placebo) } \\
\text { - } & \text { older adults }\end{aligned}\end{array}$ & $\begin{array}{l}\text { Low }<\text { high } \\
\text { Low }>\text { high }\end{array}$ \\
\hline Zhu et al. (2010) & $\begin{array}{l}26 \text { older adults, } \\
\text { age } \pm \text { SD: } 74 \pm 6 \text {; } \\
23 \text { younger adults, } \\
\text { age } \pm \text { SD: } 20 \pm 3\end{array}$ & $\begin{array}{l}\text { Flanker task with } 3 \\
\text { conditions } \\
\text { (incongruent, } \\
\text { congruent, } \\
\text { neutral) }\end{array}$ & $\begin{array}{l}\text { Behavioral data: } \\
\text { accuracy, RT; fMRI } \\
\text { data: differential brain } \\
\text { activity (Incongruent } \\
\text { versus Congruent } \\
\text { stimulus conditions) } \\
\text { flanker activation (for } \\
\text { successful trials and/or } \\
\text { error trials) }\end{array}$ & $\begin{array}{l}\text { Behavioral data: accuracy } \\
\text { RT } \\
\text { fMRI data: regions of activation in the inferior } \\
\text { and middle frontal gyri } \\
\text { In the frontal regions, cluster in the inferior and } \\
\text { middle frontal gyri } \\
\text { In older adults, the centroid location was shifted } \\
\text { by } 19.7 \mathrm{~mm} \text {. The left superior and medial frontal } \\
\text { gyri were specifically recruited, partially driven } \\
\text { by errors. Bilateral activation was also observed } \\
\text { during error processing }\end{array}$ & $\begin{array}{l}\mathrm{Y}>\mathrm{O}^{*} \\
\mathrm{Y}<\mathrm{O} \\
\mathrm{Y}>\mathrm{O}\end{array}$ \\
\hline $\begin{array}{l}\text { Ginestet et al. } \\
(2011)\end{array}$ & $\begin{array}{l}43 \text { older adults, } \\
\text { age } \pm \text { SD: } 68.2 \pm \\
13.2\end{array}$ & $\begin{array}{l}\text { N-back task with } 3 \\
\text { levels of difficulty } \\
(0-1-2-3)\end{array}$ & $\begin{array}{l}\text { Behavioral data: RT. } \\
\text { fMRI data: connectivity } \\
\text { strength = weighted } \\
\text { cost, cost-integrated } \\
\text { global and local } \\
\text { efficiencies, ranking of } \\
\text { cortical areas }\end{array}$ & $\begin{array}{l}\text { Task difficulty: } \\
\text { Weighted cost: } 1<2<3 \\
\text { cost-integrated global and local efficiencies, rankin } \\
1=2=3\end{array}$ & g of cortical areas: \\
\hline \multicolumn{6}{|l|}{ PET measures } \\
\hline $\begin{array}{l}\text { Karlsson et al. } \\
\text { (2009) }\end{array}$ & $\begin{array}{l}20 \text { older adults, } \\
\text { age (range): } 70.3 \\
(65-75) ; 20 \\
\text { younger adults, }\end{array}$ & $\begin{array}{l}\text { Condition 1: } \\
\text { resting state task; } \\
\text { Condition 2: multi- } \\
\text { source }\end{array}$ & $\begin{array}{l}\text { Behavioral data: } \\
\text { accuracy, latencies. } \\
\text { fMRI and PET } \\
\text { measurements: D1- }\end{array}$ & $\begin{array}{l}\text { Behavioral data: accuracy } \\
\text { Latencies } \\
\text { PET measurements: D1 binding potential in } \\
\text { sensorimotor, limbic and associative striatum: }\end{array}$ & $\begin{array}{l}Y=0 \\
Y<O\end{array}$ \\
\hline
\end{tabular}




\begin{tabular}{|c|c|c|c|c|c|}
\hline & $\begin{array}{l}\text { age (range): } 25.2 \\
(22-30)\end{array}$ & interference task & $\begin{array}{l}\text { receptor binding } \\
\text { potential calculated for } \\
\text { sensorimotor, limbic } \\
\text { and associative } \\
\text { striatum }\end{array}$ & $\begin{array}{ll}- & \text { in younger adults } \\
- & \text { in older adults }\end{array}$ & $\begin{array}{l}\text { rest }>\text { task } \\
\text { rest }=\text { task }\end{array}$ \\
\hline \multicolumn{6}{|l|}{ Pupil measures } \\
\hline Allard et al. (2010) & $\begin{array}{l}106 \text { older adults, } \\
\text { age } \pm \text { SD: } 72.4 \pm \\
7.2 ; 85 \text { younger } \\
\text { adults, age } \pm \text { SD: } \\
19.7 \pm 1.8\end{array}$ & $\begin{array}{l}\text { Viewing facial } \\
\text { stimuli of varying } \\
\text { emotions } \\
\text { (emotional images } \\
\text { and neutral } \\
\text { images) }\end{array}$ & $\begin{array}{l}\text { Pupil data: direct } \\
\text { measure of change in } \\
\text { pupil dilation of the left } \\
\text { eye toward emotional- } \\
\text { neutral face pairs }\end{array}$ & $\begin{array}{l}\text { Pupil data: Changes in pupil dilation: } \\
\text { For emotional and neutral images } \\
\text { - Mood and emotion in older groups: positive or } \\
\text { negative < neutral }\end{array}$ & $\mathrm{Y}>\mathrm{O}$ \\
\hline $\begin{array}{l}\text { Piquado et al. } \\
\text { (2010) }\end{array}$ & $\begin{array}{l}15 \text { older adults, } \\
\text { age (range): } 74.1 \\
(67-83) ; 15 \\
\text { younger adults, } \\
\text { age (range): } 22.6 \\
(19-27)\end{array}$ & $\begin{array}{l}\text { Condition 1: } \\
\text { Listening to } \\
\text { spoken digit lists } \\
\text { that varied in } \\
\text { length }(4,6 \text {, or } 8 \\
\text { digits) and } \\
\text { retaining them } \\
\text { briefly for recall. } \\
\text { Condition } 2: \\
\text { Listening to } \\
\text { sentence types } \\
\text { that varied in } \\
\text { length ( } 9 \text { or } 12 \\
\text { words) and syntax } \\
\text { and retaining } \\
\text { them briefly for }\end{array}$ & $\begin{array}{l}\text { Behavioral data: recall } \\
\text { accuracy for lists or } \\
\text { sentences correctly } \\
\text { reported; Pupil data: } \\
\text { Pupil size of the left eye } \\
\text { only for lists or } \\
\text { sentences correctly } \\
\text { reported }\end{array}$ & $\begin{array}{l}\text { Condition } 1 \text { - Behavioral data: recall accuracy } \\
\text { Pupil data: pupil size at each point } \\
\text { Normalized pupil size measures } \\
\begin{array}{l}\text { - } \\
\text { - } \\
\text { as task ding the condition } \\
\text { groups }\end{array} \\
\text { Condition } 2 \text { - Behavioral data: recall accuracy } \\
\text { Pupil data: normalized pupil sizes measures } \\
\text { Sentences that varied } \\
\text { - In length during retention interval } \\
\text { - In syntax } \\
\text { Normalized pupil size in older adults during }\end{array}$ & $\begin{array}{l}Y>O^{*} \\
Y>0 \\
Y<O \\
4 \text { digit list }<6 \\
\text { digit list }<8 \text { digit } \\
\text { list; } \\
Y=0 \\
Y<0 \\
9 \text { words }<12 \\
\text { words } \\
\text { object-relative } \\
\text { sentences = }\end{array}$ \\
\hline
\end{tabular}




\begin{tabular}{|c|c|c|c|c|c|}
\hline & & recall. & & retention interval & $\begin{array}{l}\text { subject-relative } \\
\text { sentences }\end{array}$ \\
\hline $\begin{array}{l}\text { Dragan et al. } \\
(2017)^{a}\end{array}$ & $\begin{array}{l}10 \text { older adults, } \\
\text { age: } 66.4 \text {, MOCA: } \\
28.1,17 \text { younger } \\
\text { adults, age } \pm \text { SD: } \\
22.8 \pm 3.1\end{array}$ & $\begin{array}{l}\text { Condition 1: } \\
\text { Flicker change } \\
\text { detection task } \\
\text { Condition 2: } \\
\text { Target detection } \\
\text { task }\end{array}$ & $\begin{array}{l}\text { Eye data: } \\
\text { Visual search: } \\
\text { Average repeated } \\
\text { entropy, fixation times } \\
\text { and location, number } \\
\text { of fixations, scene } \\
\text { old/new judgments } \\
\text { search times } \\
\text { Pupil data: Peak } \\
\text { velocity; response } \\
\text { velocity : change in } \\
\text { pupil size due to } \\
\text { stimulus onset }\end{array}$ & $\begin{array}{l}\text { Condition } 1 \\
\text { Visual search: } \\
\text { Entropy from center of movement } \\
\text { Fixation durations in repeated trials } \\
\text { Number of fixations } \\
\text { Search times in repeated trials } \\
\text { Pupil data: } \\
\text { Peak velocity } \\
\text { Only in younger adults, faster velocities in } \\
\text { repeated trials than did novel trails } \\
\text { Condition } 2 \\
\text { Visual search: } \\
\text { Search times in repeated trials } \\
\text { Pupil data: } \\
\text { Change in pupil size } \\
\text { For young and old groups, faster velocities in } \\
\text { repeated trials than did novel trails }\end{array}$ & $\begin{array}{l}Y<O \\
Y<O \\
Y<O \\
Y<O\end{array}$ \\
\hline \multicolumn{6}{|l|}{$\begin{array}{l}\text { Cardiovascular } \\
\text { measures }\end{array}$} \\
\hline $\begin{array}{l}\text { Hess and Ennis } \\
\text { (2012) }\end{array}$ & $\begin{array}{l}51 \text { older adults, } \\
\text { age (range): } 70.9 \\
\text { (62-84); } 52 \\
\text { younger adults, } \\
\text { age (range): } 31.6\end{array}$ & $\begin{array}{l}\text { Condition 1: } \\
\text { Addition task (low } \\
\text { demand) - } \\
\text { substraction task } \\
\text { (high demand). }\end{array}$ & $\begin{array}{l}\text { Cardiovascular data for } \\
\text { each phase: single } \\
\text { changes in systolic and } \\
\text { diastolic blood pressure } \\
\text { and heart rate }\end{array}$ & $\begin{array}{l}\text { Cardiovascular data: } \\
\text { Change in systolic blood pressure } \\
\text { Heart rate: younger adults > older adults } \\
\text { Change in systolic and diastolic blood pressure in }\end{array}$ & $\begin{array}{l}Y<O \\
Y<O\end{array}$ \\
\hline
\end{tabular}




\begin{tabular}{|c|c|c|c|c|c|}
\hline & $(19-45)$ & $\begin{array}{l}\text { Condition 2: } \\
\text { multiplication } \\
\text { problems }\end{array}$ & responses & older adults & Low $>$ high \\
\hline Ennis et al. (2013) & $\begin{array}{l}57 \text { older adults, } \\
\text { age } \pm \text { SD: } 73.0 \pm \\
4.6 ; 59 \text { younger } \\
\text { adults, age } \pm \text { SD: } \\
32.3 \pm 5.5\end{array}$ & $\begin{array}{l}\text { Memory search } \\
\text { task with different } \\
\text { levels of difficulty } \\
\text { (size of the } \\
\text { memory set from } \\
2 \text { to } 10 \\
\text { consonants) }\end{array}$ & $\begin{array}{l}\text { Cardiovascular data: } \\
\text { Changes in systolic } \\
\text { blood pressure }\end{array}$ & $\begin{array}{l}\text { Cardiovascular data: Changes in systolic blood } \\
\text { pressure at all levels of the task } \\
\text { Task difficulty: } \\
\quad \text { - in older adults } \\
\text { - in younger adults }\end{array}$ & $\begin{array}{l}Y<0 \\
\text { level } 8>\text { level } 10 \\
\text { level } 8=\text { level } 10\end{array}$ \\
\hline $\begin{array}{l}\text { Vermeij et al. } \\
(2014)\end{array}$ & $\begin{array}{l}14 \text { older adults, } \\
\text { age } \pm \text { SD: } 70.3 \pm \\
4.7 ; 14 \text { younger } \\
\text { adults, age } \pm \text { SD: } \\
26.4 \pm 3\end{array}$ & $\begin{array}{l}\text { N-back task with } \\
\text { two levels }(0-2)\end{array}$ & $\begin{array}{l}\text { fNIRS data and } \\
\text { photoplethysmography } \\
\text { : frequency oscillations } \\
\text { of cerebral } \\
\text { hemodynamics and } \\
\text { blood pressure }\end{array}$ & $\begin{array}{l}\text { VLFO of } \mathrm{O} 2 \mathrm{Hb} \text { during the } 0 \text {-back condition } \\
\text { (control condition) } \\
\text { Blood pressure } \\
\text { Cerebral oscillations }(\mathrm{O} 2 \mathrm{Hb} \text { and } \mathrm{tHb}) \text { : } \\
\quad-\quad \text { in young group: } \\
\quad \text { - in older group } \\
\text { Blood pressure in both groups }\end{array}$ & $\begin{array}{l}Y>0 \\
Y<0 \\
0 \text {-back }>2 \text {-back } \\
0 \text {-back = 2-back } \\
0 \text { back }<2 \text {-back }\end{array}$ \\
\hline \multicolumn{6}{|c|}{$\begin{array}{l}\text { Abbreviations: BA: Brodmann Area; COWAT: Controlled Oral Word Association Test; CVLT: California } \\
\text { fMRI: functional magnetic resonance imaging; IQ: Intellectual Quotient: NS: non significant; SD: Stanc } \\
\text { WAIS: Wechler Adult Intelligence Scale; WM: Working Memory; WCST: Wisconsin Card Sorting Test }\end{array}$} \\
\hline \multicolumn{6}{|c|}{ a only data regarding younger adults and healthy older adults are displayed in this table } \\
\hline
\end{tabular}


${ }^{2}$ low = high: no significant differences in behavioral or physiological measures between the high and low demand conditions

low > high: significant decrease in behavioral or physiological measures in the high demand condition compared to low demand condition

low < high: significant increase in behavioral or physiological measures in the high demand condition compared to low demand condition

* tendancy to be significant 
Table 2. Studies that used physiological measures in $\mathrm{MCl}$ and $\mathrm{AD}$

\begin{tabular}{|c|c|c|c|c|c|}
\hline References & $\begin{array}{l}\text { Population } \\
\text { characteristics }\end{array}$ & Task paradigm & Outcomes & Main results & $\begin{array}{l}\text { Between-group or } \\
\text { within group } \\
\text { comparisons }^{1}\end{array}$ \\
\hline \multicolumn{6}{|l|}{$\begin{array}{l}\text { Resting state } \\
\text { conditions }\end{array}$} \\
\hline \multicolumn{6}{|l|}{ EEG / MEG measures } \\
\hline Babiloni et al. (2006) & $\begin{array}{l}193 \text { patients with mild } \\
\text { AD age } \pm \text { SE: } 76.2 \pm 0.6 \text {, } \\
\text { MMSE score } \pm \text { SE: } 20.7 \\
\pm 0.2 ; 155 \text { patients } \\
\text { with } \mathrm{MCl} \text {, age } \pm \text { SE: } \\
72.1 \pm 0.7, \mathrm{MMSE} \\
\text { score } \pm \mathrm{SE}: 25.9 \pm 0.2 ; \\
126 \text { healthy older } \\
\text { adults, age } \pm \text { SE: } 65.4 \pm \\
0.9, \mathrm{MMSE} \text { score } \pm \text { SE: } \\
28.3 \pm 0.1\end{array}$ & $\begin{array}{l}\text { Resting-state eyes- } \\
\text { closed condition }\end{array}$ & $\begin{array}{l}\text { EEG data: cortical } \\
\text { sources of EEG } \\
\text { rhythms (delta, theta, } \\
\text { alpha } 1 \text {, alpha 2, beta } \\
1 \text {, and beta 2) }\end{array}$ & $\begin{array}{l}\text { EEG data: } \\
\text { Parietal, occipital, } \\
\text { temporal, and limbic } \\
\text { alpha } 1 \text { sources } \\
\text { Occipital delta sources } \\
\text { These } 5 \text { EEG sources } \\
\text { were correlated with } \\
\text { MMSE score in all } \\
\text { subjects }\end{array}$ & $\begin{array}{l}\mathrm{O}>\mathrm{MCl}>\mathrm{AD} \\
\mathrm{O}<\mathrm{MCl}<\mathrm{AD}\end{array}$ \\
\hline Stam et al. (2006) & $\begin{array}{l}18 \text { patients with AD, } \\
\text { age } \pm \text { SD: } 72.1 \pm 5.6, \\
\text { MMSE score (range): } \\
19.2(13-25) ; 18 \\
\text { healthy older adults, } \\
\text { age } \pm \text { SD: } 69.1 \pm 6.8, \\
\text { MMSE score (range): } \\
29 \text { (27-30) }\end{array}$ & $\begin{array}{l}\text { eyes-closed no task } \\
\text { state }\end{array}$ & $\begin{array}{l}\text { MEG data: Functional } \\
\text { connectivity = } \\
\text { synchronization } \\
\text { likelihood and } \\
\text { coherence (delta, } \\
\text { theta, alpha 1, alpha 2, } \\
\text { beta and gamma } \\
\text { bands) }\end{array}$ & $\begin{array}{l}\text { Alpha } 1 \text { et beta band } \\
\text { for long distance } \\
\text { intrahemispheric } \\
\text { interactions } \\
\text { Functional connectivity } \\
\text { locally in the theta } \\
\text { (centro-parietal } \\
\text { regions), beta and }\end{array}$ & $\begin{array}{l}O>A D \\
O<A D\end{array}$ \\
\hline
\end{tabular}




\begin{tabular}{|c|c|c|c|c|c|}
\hline & & & & $\begin{array}{l}\text { gamma bands } \\
\text { (occipito-parietal } \\
\text { regions) } \\
\text { In patients with AD, } \\
\text { significant correlations } \\
\text { between alpha 1, alpha } \\
2 \text { and beta band } \\
\text { synchronization } \\
\text { likelihood and MMSE } \\
\text { scores }\end{array}$ & \\
\hline Babiloni et al. (2015) & $\begin{array}{l}90 \text { patients with } \mathrm{AD} \\
\text { age } \pm \text { SE: } 72.3 \pm 0.8, \\
\text { MMSE score } \pm \text { SE: } 19 \pm \\
0.4 ; 100 \text { patients with } \\
\mathrm{MCl} \text {, age } \pm \text { SE: } 70.7 \pm \\
0.8, \mathrm{MMSE} \text { score } \pm \mathrm{SE}: \\
27.4 \pm 0.1 ; 45 \text { healthy } \\
\text { older adults: age } \pm \mathrm{SE}: \\
70.1 \pm 1.1, \mathrm{MMSE} \\
\text { score } \pm \text { SE: } 29.1 \pm 0.2\end{array}$ & $\begin{array}{l}\text { Resting-state eyes- } \\
\text { closed EEG rhythms: } \\
\text { alpha } 1 \text { and } 2 \\
\text { Structural MRIs }\end{array}$ & $\begin{array}{l}\text { EEG data: cortical } \\
\text { alpha rhythms } \\
\text { Structural MRIs: grey } \\
\text { matter density } \\
\text { EEG recordings were } \\
\text { available in } 2 \\
\text { subgroups on } 19 \\
\text { healthy older adults } \\
\text { and } 14 \text { AD subjects. }\end{array}$ & $\begin{array}{l}\text { Significant correlation } \\
\text { between amplitude of } \\
\text { occipital sources of } \\
\text { alpha } 1 \text { rhythms and } \\
\text { MMSE score in healthy } \\
\text { older adults, patients } \\
\text { with MCl and patients } \\
\text { with AD } \\
\text { Correlation between } \\
\text { the amplitude of } \\
\text { occipital alpha } 1 \\
\text { sources and MMSE } \\
\text { score across all } \\
\text { subjects }\end{array}$ & $\mathrm{O}>\mathrm{MCl}$ and $\mathrm{AD}$ \\
\hline & & & & Structural MRIs: & \\
\hline
\end{tabular}




\begin{tabular}{|c|c|c|c|c|c|}
\hline & & & & $\begin{array}{l}\text { Occipital grey matter } \\
\text { density }\end{array}$ & \\
\hline Hata et al. (2016) & $\begin{array}{l}28 \text { patients with } \\
\text { probable AD age } \pm \text { SE: } \\
74.2 \pm 8.9, \mathrm{MMSE} \\
\text { score } \pm \text { SE: } 18.7 \pm 4.5 \text {; } \\
30 \text { healthy older } \\
\text { adults: age } \pm \text { SE: } 70.1 \pm \\
1.1, \mathrm{MMSE} \text { score } \pm \mathrm{SE}: \\
29.2 \pm 1.0\end{array}$ & $\begin{array}{l}\text { Resting-state during } \\
\text { eyes open and closed } \\
\text { state }\end{array}$ & $\begin{array}{l}\text { EEG data: } \\
\text { Artifact-free EEG } \\
\text { (delta, theta, alpha1, } \\
\text { alpha2, beta1, beta2 } \\
\text { functional connectivity } \\
=\text { lagged phase } \\
\text { synchronisation }\end{array}$ & $\begin{array}{l}\text { EEG data: } \\
\text { Delta lagged phase } \\
\text { synchronization over } \\
\text { most cortical regions } \\
\text { Theta lagged phase } \\
\text { synchronization } \\
\text { between the right } \\
\text { DLPFC and right } \\
\text { posterior IPL } \\
\text { Positive correlation } \\
\text { between } 4 \text { of the delta } \\
\text { band connections and } \\
\text { MMSE score } \\
\text { The four functional } \\
\text { connections included: } \\
\text { (1) the left and right } \\
\text { middle temporal area } \\
\text { (MT), ( } 2 \text { ) the right } \\
\text { frontal eye field (FEF) } \\
\text { and left posterior } \\
\text { inferior parietal lobule } \\
\text { (pIPL), ( } 3 \text { ) } \\
\text { the anterior cingulate } \\
\text { cortex (aCC) and left }\end{array}$ & $\begin{array}{l}0=A D \\
0>A D \\
0>A D\end{array}$ \\
\hline
\end{tabular}




\begin{tabular}{|c|c|c|c|c|}
\hline & & & $\begin{array}{l}\text { pIPL, and (4) the left } \\
\text { anterior inferior } \\
\text { parietal lobule } \\
\text { (aIPL) and left } \\
\text { hippocampal } \\
\text { formation (HF). } \\
\text { Negative correlation } \\
\text { between delta } \\
\text { functional connection } \\
\text { between right MT and } \\
\text { right Aud and CDR } \\
\text { scores }\end{array}$ & 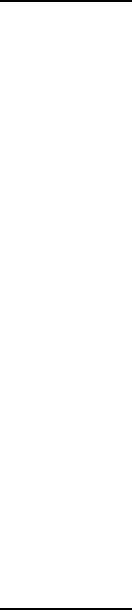 \\
\hline \multicolumn{5}{|l|}{ fMRI measures } \\
\hline \multirow[t]{3}{*}{$\begin{array}{l}\text { Binnewijzend et al. } \\
\text { (2014) }\end{array}$} & $\begin{array}{l}39 \text { patients with } A D, \\
\text { age } \pm \text { SD: } 67 \pm 8, \\
\text { MMSE } \pm \text { SD: } 22 \pm 3 ; 43 \\
\text { healthy older adults, } \\
\text { age } \pm \text { SD: } 69 \pm 7 \text { MMSE }\end{array}$ & $\begin{array}{l}\text { fMRI data: brain } \\
\text { connectivity = EC } \\
\text { mapping }\end{array}$ & $\begin{array}{l}\text { fMRI data: EC values } \\
\text { located in the } \\
\text { precuneus and the } \\
\text { occipital cortex }\end{array}$ & $\begin{array}{l}O>A D \\
O<A D\end{array}$ \\
\hline & \pm SD: $29 \pm 1$ & & $\begin{array}{l}\text { Mean EC values were } \\
\text { more spread across } \\
\text { the entire cingulate } \\
\text { cortex }\end{array}$ & $O>A D$ \\
\hline & & & $\begin{array}{l}\text { EC values in the left } \\
\text { and right occipital } \\
\text { cortex }\end{array}$ & $O<A D$ \\
\hline
\end{tabular}


EC values found

bilaterally in the

medial frontal cortex

Both lower EC in the

occipital regions and

higher EC in the medial

frontal regions were

related to MMSE

scores across groups

In AD patients, no

relation between EC

and MMSE scores was

found.

Lower occipital EC

values were associated

with lower

performance on the

MMSE in healthy older

adults

Pupil measures

Bittner et al. (2014)

$\begin{array}{lll}66 \text { patients with } A D, & \text { Pupillary light reflexes } & \text { Pupil data: pupil size, } \\ \text { age } \pm \text { SD: } 74.4 \pm 7.5, & \text { of the left eye: } & \text { latency, amplitude, } \\ \text { MMSE } \pm \text { SD: } 20.4 \pm 5.0 ; & \text { Repetitive stimulation } & \text { relative amplitude }\end{array}$

Effect of repetitive

measurement on

pupillary light reflexes: $\quad 0<\mathrm{MCl} ; \mathrm{O}<\mathrm{AD}$

42 patients with $\mathrm{MCl}$,

Pupil size decrease

$\mathrm{MCl}<\mathrm{AD} *$ 
age \pm SD: $69.8 \pm 8.4$,

MMSE \pm SD: $25.7 \pm 2.4$,

44 healthy older

adults, age \pm SD: $66.4 \pm$

8.3, MMSE \pm SD: 28.8

$\pm 1.2$

over time

$\mathrm{O}>\mathrm{MCl}^{*} ; \mathrm{O}>\mathrm{AD}$

Pupil diameter

decrease over time

Amplitude increase

over time

After correcting for

age, significant

correlation between

MMSE score and pupil

size, amplitude, and

relative amplitude

In $\mathrm{MCl}$ patients,

significant correlation

between MMSE score

and amplitude, relative

amplitude and latency

under repetitive

stimulation

In AD patients,

significant correlation

between MMSE score

and amplitude, relative

amplitude and latency

under repetitive

stimulation 


\begin{tabular}{|c|c|c|c|c|c|}
\hline \multicolumn{6}{|l|}{$\begin{array}{l}\text { While performing a } \\
\text { cognitive task }\end{array}$} \\
\hline \multicolumn{6}{|l|}{ EEG / MEG measures } \\
\hline Cummins et al. (2008) & $\begin{array}{l}12 \text { patients with } \\
\text { amnestic } \mathrm{MCl} \text {, age } \pm \\
\text { SD: } 70.2 \pm 8.9 ; 12 \\
\text { healthy older adults, } \\
\text { age } \pm \text { SD: } 67.8 \pm 8.3\end{array}$ & $\begin{array}{l}\text { Modified version of } \\
\text { the Sternberg } \\
\text { recognition task with } \\
\text { low ( } 4 \text { words) or high } \\
\text { ( } 8 \text { words) memory } \\
\text { load. Recognition and } \\
\text { retention phases }\end{array}$ & EEG data: theta power & $\begin{array}{l}\text { EEG data: } \\
\text { During recognition } \\
\text { interval, theta power } \\
\text { around the frontal } \\
\text { midline electrode } \\
\text { During retention } \\
\text { interval, theta power } \\
\text { at parietal and } \\
\text { temporal electrodes }\end{array}$ & $\begin{array}{l}\mathrm{O}>\mathrm{MCl} \\
\mathrm{O}>\mathrm{MCl} \\
\text { low }>\text { high }^{2} \\
\text { low }=\text { high }\end{array}$ \\
\hline & & & & $\begin{array}{l}\text { Task difficulty: theta } \\
\text { power in patients with } \\
\text { aMCl } \\
\text { theta power in controls }\end{array}$ & \\
\hline Bajo et al. (2010) & $\begin{array}{l}22 \text { patients with } \mathrm{MCl} \text {, } \\
\text { age } \pm \text { SD: } 74.8 \pm 3 \text {, } \\
\text { MMSE score } \pm \text { SD: } 27.7 \\
\pm 1 ; 19 \text { healthy older } \\
\text { adults, age } \pm \text { SD: } 71.6 \pm \\
8, \text { MMSE score } \pm \text { SD: } \\
29.5 \pm 0.7\end{array}$ & $\begin{array}{l}\text { Modified version of } \\
\text { the Sternberg task }\end{array}$ & $\begin{array}{l}\text { Behavioral data: hit } \\
\text { responses; MEG data: } \\
\text { synchronization } \\
\text { likelihood = index of } \\
\text { functional connectivity } \\
\text { (alpha 1, alpha 2, beta } \\
1 \text {, beta 2, gamma) }\end{array}$ & $\begin{array}{l}\text { Behavioral data: hit } \\
\text { responses } \\
\text { MEG data: } \\
\text { Interhemispheric } \\
\text { synchronization during } \\
\text { the memory task } \\
\text { between left and right } \\
\text { anterior temporo- } \\
\text { frontal regions (in all } \\
\text { bands) and in posterior } \\
\text { regions in the gamma }\end{array}$ & $\begin{array}{l}\mathrm{O}=\mathrm{MCl} \\
\mathrm{O}<\mathrm{MCl}\end{array}$ \\
\hline
\end{tabular}




\begin{tabular}{|c|c|c|c|c|c|}
\hline Maestu et al. (2008) & $\begin{array}{l}15 \text { patients with } \mathrm{MCl}, \\
\text { age } \pm \text { SD: } 74.8 \pm 3.0 \\
\text { MMSE score } \pm \text { SD: } 27.7 \\
\pm 1 ; 20 \text { healthy older } \\
\text { adults, age } \pm \text { SD: } 71.6 \pm \\
8, \text { MMSE score } \pm \text { SD: } \\
29.5 \pm 0.7\end{array}$ & $\begin{array}{l}\text { Modified version of } \\
\text { the Sternberg letter- } \\
\text { probe task }\end{array}$ & $\begin{array}{l}\text { Behavioral data: total } \\
\text { number of hits, misses } \\
\text { and RT } \\
\text { MEG data: brain } \\
\text { magnetic profiles }\end{array}$ & $\begin{array}{l}\text { Behavioral data: total } \\
\text { number of hits, misses } \\
\text { and RT } \\
\text { MEG data: bilateral } \\
\text { activity in the ventral } \\
\text { pathway in both the } \\
\text { target and the non- } \\
\text { target stimuli }\end{array}$ & $\mathrm{O}<\mathrm{MCl}$ \\
\hline $\begin{array}{l}\text { Aurtenetxe et al. } \\
\text { (2013) }\end{array}$ & $\begin{array}{l}12 \text { patients with aMCl, } \\
\text { age } \pm \text { SD: } 74.8 \pm 4.8, \\
\text { MMSE score } \pm \text { SD: } 25.3 \\
\pm 1.8 ; 13 \text { healthy older } \\
\text { adults, age } \pm \text { SD: } 70.6 \pm \\
6.3, \text { MMSE score } \pm \text { SD: } \\
28.7 \pm 1.4\end{array}$ & $\begin{array}{l}\text { Modified version of } \\
\text { the Sternberg task }\end{array}$ & $\begin{array}{l}\text { Behavioral } \\
\text { performance: hits, } \\
\text { errors and correct } \\
\text { rejections; MEG data: } \\
\text { spectral power } \\
\text { dynamics in source } \\
\text { space on the } \\
\text { recognition phase of } \\
\text { the target stimuli } \\
\text { (theta }(4-8 \mathrm{~Hz}) \text {, alpha } \\
(8-12 \mathrm{~Hz}) \text {, beta (12- } \\
30 \mathrm{~Hz}), \text { gamma }(30- \\
45 \mathrm{H}))\end{array}$ & $\begin{array}{l}\text { Behavioral data: hits, } \\
\text { errors and correct } \\
\text { rejections } \\
\text { MEG data: Differences } \\
\text { to target stimuli in } \\
\text { spatial-time frequency } \\
\text { patterns in theta, } \\
\text { alpha, beta and } \\
\text { gamma spectral bands. } \\
\text { Theta over the right } \\
\text { frontal pole at early } \\
\text { latencies } \\
\text { Beta band in right } \\
\text { fronto-parietal regions } \\
\text { at late latencies } \\
\text { Alpha band in the }\end{array}$ & $\begin{array}{l}\mathrm{O} \neq \mathrm{MCl} \\
\mathrm{O}<\mathrm{MCl} \\
\mathrm{O}<\mathrm{MCl}\end{array}$ \\
\hline
\end{tabular}




\begin{tabular}{|c|c|c|c|c|c|}
\hline & & & & $\begin{array}{l}\text { temporo-occipital } \\
\text { region of the right } \\
\text { hemisphere between } \\
489 \text { and } 528 \text { ms and } \\
\text { gamma power over left } \\
\text { parietal regions } \\
\text { between } 372 \text { and } 489 \\
\text { ms }\end{array}$ & \\
\hline Ahmaldou et al. (2014) & $\begin{array}{l}18 \text { patients with } \mathrm{MCl} \\
\text { age } \pm \text { SD: } 74.8 \pm 3 ; 19 \\
\text { healthy older adults, } \\
\text { age } \pm \text { SD: } 71.6 \pm 8\end{array}$ & Sternberg Task & $\begin{array}{l}\text { Behavioral data: } \\
\text { number of hits; MEG } \\
\text { data: networks' } \\
\text { complexities were } \\
\text { measured by Graph } \\
\text { Index Complexity and } \\
\text { Efficiency Complexity }\end{array}$ & $\begin{array}{l}\text { Behavioral data } \\
\text { MEG data: Complexity } \\
\text { of functional networks } \\
\text { at both alpha and } \\
\text { theta band and more } \\
\text { pronounced at the } \\
\text { theta band in the } \\
\text { whole brain and intra } \\
\text { left hemisphere }\end{array}$ & $\begin{array}{l}\mathrm{O}=\mathrm{MCl} \\
\mathrm{O}>\mathrm{MCl}\end{array}$ \\
\hline Lopez et al. (2014) & $\begin{array}{l}38 \text { patients with } \mathrm{MCl} \\
\text { age } \pm \text { SD: } 72.5 \pm 4.5 \\
\text { MMSE score } \pm \text { SD: } 27.1 \\
\pm 2.2 ; 32 \text { controls, age } \\
\pm \text { SD: } 71.8 \pm 3.8, \mathrm{MMSE} \\
\text { score } \pm \text { SD: } 29.3 \pm 0.9\end{array}$ & $\begin{array}{l}\text { Condition 1: resting } \\
\text { state } \\
\text { Condition } 2 \text { and 3: 1- } \\
\text { and 3- subtraction } \\
\text { tasks }\end{array}$ & $\begin{array}{l}\text { MEG data: Functional } \\
\text { connectivity assessed } \\
\text { with phase locking } \\
\text { value in the five } \\
\text { frequency bands }\end{array}$ & $\begin{array}{l}\text { MEG data: } \\
\text { In resting-state } \\
\text { condition: } \\
\text { Connectivity values in } \\
\text { low frequency-bands } \\
\text { (frontal delta and } \\
\text { antero-posterio right } \\
\text { theta) } \\
\text { Connectivity values in } \\
\text { the alpha band, }\end{array}$ & $\begin{array}{l}\mathrm{O}<\mathrm{MCl} \\
\mathrm{O}>\mathrm{MCl}\end{array}$ \\
\hline
\end{tabular}




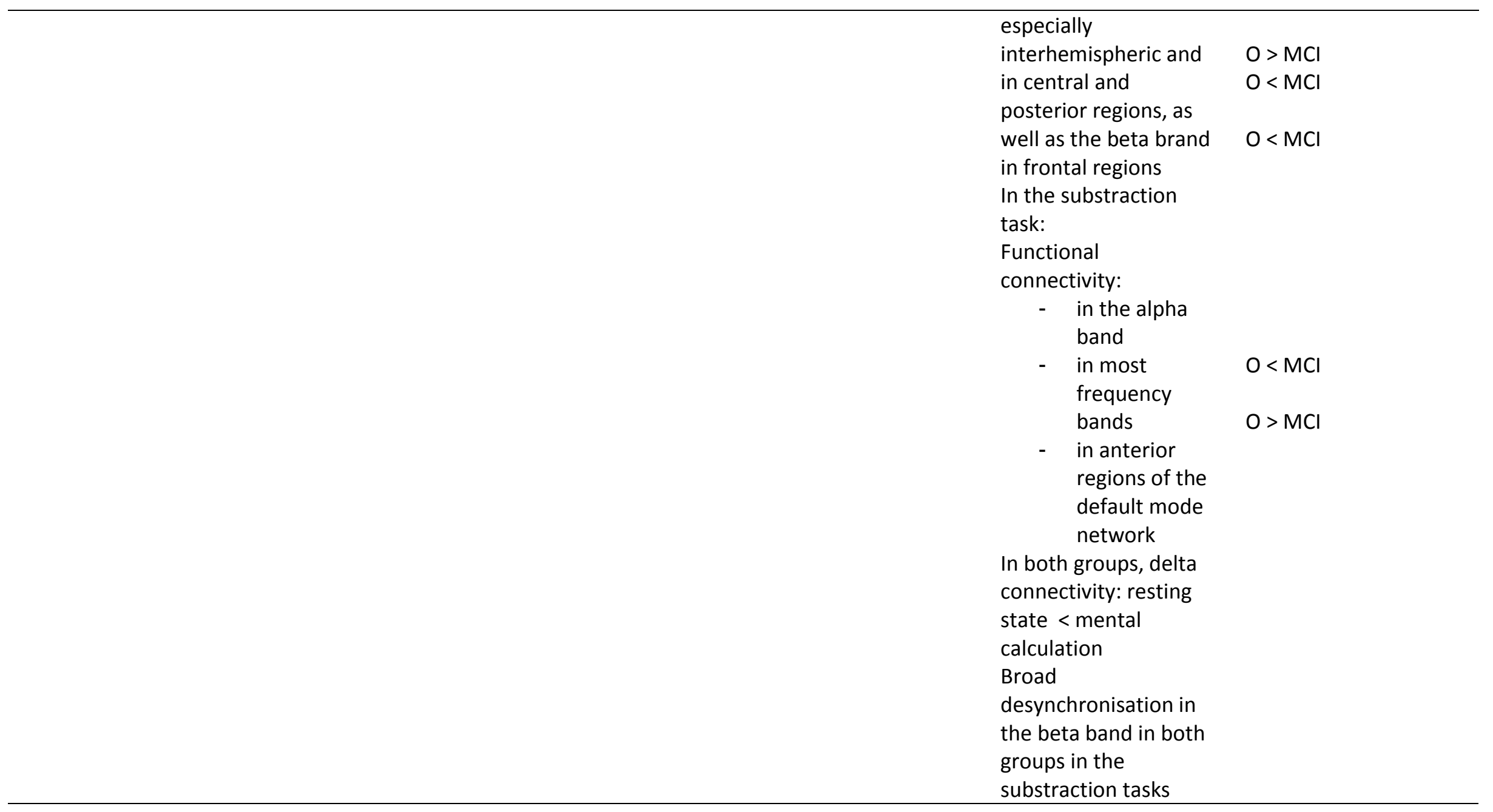




\begin{tabular}{|c|c|c|c|c|c|}
\hline & & & & $\begin{array}{l}\text { compared to resting } \\
\text { state. Similar findings } \\
\text { were found in the } \\
\text { gama band in both } \\
\text { groups. } \\
\text { Connectivity changes } \\
\text { in theta band between } \\
\text { task and resting state } \\
\text { Connectivity changes } \\
\text { in alpha band between } \\
\text { task and resting state }\end{array}$ & \\
\hline Chapman et al. (2007) & $\begin{array}{l}12 \text { patients with } A D \text {, } \\
\text { age } \pm \text { SD: } 75.8 \pm 4.5 ; 12 \\
\text { healthy older adults, } \\
\text { age } \pm \text { SD: } 74.2 \pm 4.8\end{array}$ & $\begin{array}{l}\text { The Number-Letter } \\
\text { paradigm }\end{array}$ & $\begin{array}{l}\text { Behavioral data: } \\
\text { correct trials of the } \\
\text { number-letter task; } \\
\text { EEG data: ERPs }\end{array}$ & $\begin{array}{l}\text { Behavioral data: } \\
\text { correct trials of the } \\
\text { number-letter task; } \\
\text { EEG data: ERPs (C145, } \\
\text { C250, P3) differences } \\
\text { between the relevant } \\
\text { and irrelevant stimuli }\end{array}$ & $O=A D$ \\
\hline Hidasi et al. (2007) & $\begin{array}{l}10 \text { patients with AD, } \\
\text { age (range): } 67.4 \text { (58- } \\
79), \text { MMSE score } \\
\text { (range): } 29.8 \text { ( } 29-30) ; \\
14 \text { healthy older } \\
\text { adults, age (range): } \\
67.2 \text { (55-78), MMSE } \\
\text { score (range): } 20.21 \\
\text { (16-24) }\end{array}$ & $\begin{array}{l}2 \text { conditions: eyes } \\
\text { closed (before-task } \\
\text { period) and reverse } \\
\text { counting task with } \\
\text { eyes closed. }\end{array}$ & $\begin{array}{l}\text { EEG data: relative } \\
\text { frequency spectra of } \\
\text { the } 6 \text { frequency bands, } \\
\text { coherence for } \\
\text { interhemispheric and } \\
\text { intrahemispheric } \\
\text { short-range and long- } \\
\text { range electrode pairs } \\
\text { recorded before and } \\
\text { after the execution of }\end{array}$ & $\begin{array}{l}\text { EEG data: Before and } \\
\text { after task } \\
\text { Theta } \\
\text { Beta1 } \\
\text { After task, alpha } 2 \\
\text { band } \\
\text { Coherence values in } \\
\text { the alpha 1, alpha2 } \\
\text { and beta2 bands } \\
\text { Beta2 coherence }\end{array}$ & $\begin{array}{l}0<A D \\
O>A D \\
O<A D \\
O \neq A D \\
O<A D\end{array}$ \\
\hline
\end{tabular}




\begin{tabular}{|c|c|c|c|c|c|}
\hline & & & $\begin{array}{l}\text { a cognitive task (delta, } \\
\text { theta, alpha1, alpha2, } \\
\text { beta1, beta2) }\end{array}$ & $\begin{array}{l}\text { values, irrespective of } \\
\text { task performance } \\
\text { Increase in fast (alpha } \\
2 \text { and beta 1), and a } \\
\text { decrease in slow } \\
\text { (delta) frequencies in } \\
\text { patients with AD } \\
\text { following the } \\
\text { completion of the } \\
\text { cognitive task } \\
\text { Decrease of alpha } 2 \\
\text { band after the task in } \\
\text { the healthy older } \\
\text { adults }\end{array}$ & \\
\hline $\begin{array}{l}\text { van Der Hiele et al. } \\
\text { (2007) }\end{array}$ & $\begin{array}{l}16 \text { patients with } A D, \\
\text { age } \pm \text { SD: } 78 \pm 8, \\
\text { MMSE score } \pm \text { SD: } 21 \pm \\
4 ; 18 \text { patients with } \\
\mathrm{MCl} \text {, age } \pm \text { SD: } 74 \pm 5 \text {, } \\
\text { MMSE score } \pm \text { SD: } 24 \pm \\
\text { 3; } 22 \text { healthy older } \\
\text { adults, age } \pm \text { SD: } 70 \pm \\
\text { 5, MMSE score } \pm \text { SD: } \\
28 \pm 1\end{array}$ & $\begin{array}{l}\text { Condition 1: } \\
\text { Resting state Condition } \\
\text { 2: picture learning } \\
\text { task } \\
\text { (memory activation) }\end{array}$ & $\begin{array}{l}\text { EEG data: Theta } \\
\text { relative power during } \\
\text { eyes closed; alpha } \\
\text { reactivity during the } \\
\text { task; alpha coherence } \\
\text { during eyes closed; } \\
\text { alpha coherence } \\
\text { during the task }\end{array}$ & $\begin{array}{l}\text { EEG data: Theta } \\
\text { relative power during } \\
\text { eyes closed } \\
\text { Alpha reactivity during } \\
\text { the task } \\
\text { Alpha coherence } \\
\text { Alpha reactivity during } \\
\text { task decreased in AD } \\
\text { patients only }\end{array}$ & $\begin{array}{l}\mathrm{O} \text { and } \mathrm{MCl}<\mathrm{AD} \\
\mathrm{O}>\mathrm{AD} \\
\mathrm{O}=\mathrm{AD}\end{array}$ \\
\hline van Deursen et al. & 15 patients with $A D$, & Condition 1: Resting- & EEG data: Local gamma & Gamma band power in & $\mathrm{O}$ and $\mathrm{MCl}<\mathrm{AD}$ \\
\hline
\end{tabular}




\begin{tabular}{|c|c|c|c|c|c|}
\hline (2008) & $\begin{array}{l}\text { age } \pm \text { SD: } 75.2 \pm 6.9 \\
\text { MMSE score } \pm \text { SD: } 20.8 \\
\pm 2.7 ; 20 \text { patients with } \\
\mathrm{MCl} \text {, age } \pm \text { SD: } 70.6 \pm \\
7.2, \mathrm{MMSE} \text { score } \pm \text { SD: } \\
26.3 \pm 1.6 ; 20 \text { healthy } \\
\text { older adults, age } \pm \text { SD: } \\
69.5 \pm 6.1, \mathrm{MMSE} \\
\text { score } \pm \text { SD: } 29.3 \pm 0.8\end{array}$ & $\begin{array}{l}\text { state condition (eyes } \\
\text { open), } \\
\text { Condition 2, } 3 \text { and 4: } \\
\text { music listening, story } \\
\text { listening and movie } \\
\text { watching tasks }\end{array}$ & band power & $\begin{array}{l}4 \text { conditions } \\
\text { Differences were } \\
\text { located in the parietal, } \\
\text { occipital and posterior } \\
\text { temporal regions }\end{array}$ & \\
\hline $\begin{array}{l}\text { Beuzeron-Mangina et } \\
\text { al. }(2009)^{a}\end{array}$ & $\begin{array}{l}25 \text { patients with } \\
\text { Alzheimer Disease, } \\
\text { age: } 69.9, \text { MMSE: } 26.5 \\
\pm 2.3,25 \text { healthy older } \\
\text { adults, age: } 70.4, \\
\text { MMSE: } 30.0\end{array}$ & $\begin{array}{l}\text { Memory Workload } \\
\text { Paradigm: indicate } \\
\text { whether the stimulus } \\
\text { belonged to the } \\
\text { memorized set size, by } \\
\text { pressing buttons for } \\
\text { target words and non- } \\
\text { target words }\end{array}$ & $\begin{array}{l}\text { EEG data: } \\
\text { Topographic } \\
\text { distribution of ERP } \\
\text { amplitudes } \\
\text { ERP latencies }\end{array}$ & $\begin{array}{l}\text { Topographic } \\
\text { distribution of ERP } \\
\text { amplitudes: } \\
\text { P450 amplitudes over } \\
\text { parietal and occipital } \\
\text { sites } \\
\text { ERP latencies: } \\
\text { P450 latencies over } \\
\text { anterior regions } \\
\text { P450 latencies over } \\
\text { posterior regions } \\
\text { Delayed P450 latencies } \\
\text { over pre-frontal and } \\
\text { frontal regions in AD } \\
\text { patients as opposed to } \\
\text { healthy older adults }\end{array}$ & $\begin{array}{l} \\
O<A D \\
O<A D \\
O>A D\end{array}$ \\
\hline
\end{tabular}




\begin{tabular}{|c|c|c|c|c|c|}
\hline $\begin{array}{l}\text { van Deursen et al. } \\
\text { (2011) }\end{array}$ & $\begin{array}{l}15 \text { patients with } A D \text {, } \\
\text { age } \pm \text { SD: } 75.2 \pm 6.9 \\
\text { age, MMSE score } \pm \text { SD: } \\
20.8 \pm 2.7 ; 20 \text { patients } \\
\text { with } \mathrm{MCl} \text {, age } \pm \text { SD : } \\
70.6 \pm 7.2, \mathrm{MMSE} \\
\text { score } \pm \text { SD: } 26.3 \pm 1.6 \text {; } \\
20 \text { healthy older } \\
\text { adults, age } \pm \text { SD: } 69.5 \pm \\
6.1, \text { MMSE score } \pm \text { SD: } \\
29.3 \pm 0.8\end{array}$ & $\begin{array}{l}\text { Condition 1: resting } \\
\text { state (eyes open) } \\
\text { Condition 2: auditory } \\
40-\mathrm{Hz} \text { stimulation }\end{array}$ & $\begin{array}{l}\text { EEG data: } 40-\mathrm{Hz} \text { SSR } \\
\text { power }\end{array}$ & $\begin{array}{l}\text { EEG data: } 40 \mathrm{~Hz} \text { SSR } \\
\text { power particularly in } \\
\text { the auditory cortex } \\
\text { Moderate correlation } \\
\text { between } 40-\mathrm{Hz} \text { SSR } \\
\text { and ADAS-cog score } \\
40-\mathrm{Hz} \text { SSR power: } \\
\text { resting state < } \\
\text { stimulation }\end{array}$ & $\mathrm{O}$ and $\mathrm{MCl}<\mathrm{AD}$ \\
\hline Garn et al. (2015) & $\begin{array}{l}118 \text { patients with AD, } \\
\text { median age (range): } 76 \\
\text { (52-90), median MMSE } \\
\text { score (range): } 23 \text { (26- } \\
15)\end{array}$ & $\begin{array}{l}\text { Condition 1: resting } \\
\text { state with eyes closed } \\
\text { Condition 2: face-name } \\
\text { encoding task }\end{array}$ & $\begin{array}{l}\text { EEG markers: slowing } \\
\text { (relative band powers), } \\
\text { synchrony (coherence } \\
\text { canonical correlation, } \\
\text { Granger causality) and } \\
\text { complexity (auto, } \\
\text { mutual information, } \\
\text { Shannon/Tsalis } \\
\text { entropy) }\end{array}$ & $\begin{array}{l}\text { The highest coefficient } \\
\text { of determination } \\
\text { between QEEG marker } \\
\text { and MMSE score was } \\
\text { found for the theta (4- } \\
8 \mathrm{~Hz} \text { ) relative band } \\
\text { power } \\
\text { Relative theta power } \\
\text { increased with } \\
\text { decreasing MMSE } \\
\text { score } \\
\text { MMSE scores } \\
\text { explained 33\% of the } \\
\text { variation in the relative } \\
\text { theta power during the } \\
\text { face encoding and } 31 \% \\
\text { of auto-mutual }\end{array}$ & \\
\hline
\end{tabular}




\begin{tabular}{|c|c|c|c|c|c|}
\hline & & & & $\begin{array}{l}\text { information in resting } \\
\text { state with eyes closed } \\
\text { MMSE score explained } \\
25 \% \text { of the variations } \\
\text { in the overall QEEG } \\
\text { factor } \\
\text { In probable AD, QEEG } \\
\text { coefficients of } \\
\text { determination were } \\
\text { also higher than in the } \\
\text { whole group, where } \\
\text { MMSE scores } \\
\text { explained } 51 \% \text { of the } \\
\text { variations in relative } \\
\text { theta power }\end{array}$ & \\
\hline \multicolumn{6}{|l|}{ fMRI measures } \\
\hline Bokde et al. (2006) & $\begin{array}{l}16 \text { patients with } \mathrm{MCl} \\
\text { age } \pm \text { SD: } 69.9 \pm 7.8, \\
\text { MOCA score } \pm \text { SD: } 27.2 \\
\pm 1.5 ; 19 \text { healthy older } \\
\text { adults, age } \pm \text { SD: } 66.7 \pm \\
4.2, \text { MOCA score } \pm \text { SD: } \\
29.2 \pm 1.0\end{array}$ & Face-matching task & $\begin{array}{l}\text { Behavioral data: score } \\
\text { and RT; MRI data: } \\
\text { brain activity, } \\
\text { functional connectivity } \\
\text { between the right } \\
\text { middle fusiform gyrus } \\
\text { and all other voxels in } \\
\text { the brain }\end{array}$ & 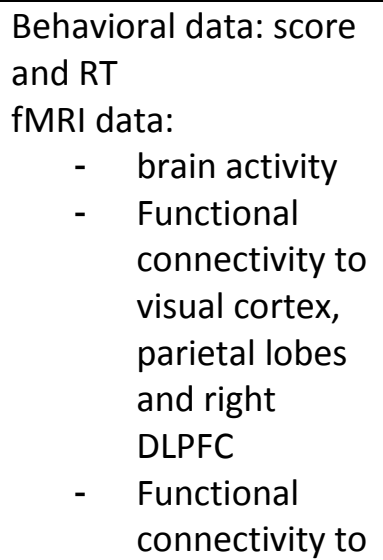 & $\begin{array}{l}\mathrm{O}=\mathrm{MCl} \\
\mathrm{O}=\mathrm{MCl} \\
\mathrm{O}>\mathrm{MCl} \\
\mathrm{O}<\mathrm{MCl} \\
\mathrm{O}>\mathrm{MCl}\end{array}$ \\
\hline
\end{tabular}




\begin{tabular}{|c|c|c|c|c|c|}
\hline & & & & $\begin{array}{l}\text { the cuneus } \\
\text { - } \quad \text { Functional } \\
\text { connectivity to } \\
\text { the frontal } \\
\text { areas, right } \\
\text { superior } \\
\text { temporal gyrus } \\
\text { and left IPL }\end{array}$ & \\
\hline Kochan et al. (2006) & $\begin{array}{l}35 \text { patients with } \mathrm{MCl} \text {, } \\
\text { age } \pm \text { SD: } 78.0 \pm 3.9, \\
\text { MMSE } \pm \text { SD: } 27.9 \pm 1.6 \\
22 \text { healthy older } \\
\text { adults, age } \pm \text { SD: } 77.2 \pm \\
3.3, \text { MMSE } \pm \text { SD: } 29.3 \pm \\
1.0\end{array}$ & $\begin{array}{l}\text { Visuospatial } \\
\text { associative working } \\
\text { memory task with } 3 \\
\text { load levels (low, } \\
\text { medium, high) }\end{array}$ & $\begin{array}{l}\text { Behavioral data: } \\
\text { Accuracy, RT and mean } \\
\text { coefficient of variation } \\
\text {; fMRI data: brain } \\
\text { activity }\end{array}$ & $\begin{array}{l}\text { Behavioral data: } \\
\text { accuracy and RT } \\
\text { fMRI data: } \\
\text { - } \\
\text { At lower loads, } \\
\text { during the } \\
\text { encoding } \\
\text { phase: Brain } \\
\text { activity in the } \\
\text { right anterior } \\
\text { cingulate and } \\
\text { right } \\
\text { precuneus } \\
\text { At higher } \\
\text { loads, brain } \\
\text { activity in the } \\
\text { right anterior } \\
\text { cingulate and } \\
\text { right } \\
\text { precuneus } \\
\text { deactivation in }\end{array}$ & $\begin{array}{l}\mathrm{O}=\mathrm{MCl} \\
\mathrm{O}<\mathrm{MCl} \\
\mathrm{O}>\mathrm{MCl} \\
\mathrm{O}<\mathrm{MCl}\end{array}$ \\
\hline
\end{tabular}




\begin{tabular}{|c|c|c|c|c|c|}
\hline & & & & $\begin{array}{l}\text { the posterior } \\
\text { cingulate- } \\
\text { medial } \\
\text { precuneus }\end{array}$ & \\
\hline Miller et al. (2008) & $\begin{array}{l}25 \text { patients with } \mathrm{MCl} \\
\text { age } \pm \text { SD: } 73.2 \pm 5.3 \\
\text { MMSE score } \pm \text { SD: } 29.4 \\
\pm 0.71\end{array}$ & $\begin{array}{l}\text { Visual scene encoding } \\
\text { task with } 3 \text { conditions: } \\
\text { 1. Fixation, } 2 \text {. Novel, } 3 . \\
\text { Repeated }\end{array}$ & $\begin{array}{l}\text { fMRI data: brain } \\
\text { activity in the } \\
\text { hippocampal activation }\end{array}$ & $\begin{array}{l}\text { fMRI data: In patients } \\
\text { with } \mathrm{MCl} \text {, greater } \\
\text { activation for novel } \\
\text { scenes compared with } \\
\text { repeated scenes in the } \\
\text { left hippocampal } \\
\text { formation } \\
\text { Greater hippocampal } \\
\text { activation predicted } \\
\text { greater degree and } \\
\text { rate of subsequent } \\
\text { cognitive decline } \\
\text { The hippocampal } \\
\text { formation was the only } \\
\text { brain region that } \\
\text { predicted cognitive } \\
\text { decline }\end{array}$ & \\
\hline Vannini et al. (2008) & $\begin{array}{l}13 \text { patients with mild } \\
A D \text {, age } \pm S D: 68.9 \pm \\
6.9 ; 13 \text { healthy older }\end{array}$ & $\begin{array}{l}\text { Angle discrimination } \\
\text { task with varying task } \\
\text { demand }\end{array}$ & $\begin{array}{l}\text { Behavioral data: } \mathrm{RT} \text {, } \\
\text { percentage of correct } \\
\text { responses; fMRI data: }\end{array}$ & $\begin{array}{l}\text { Behavioral data: RT } \\
\text { Accuracy } \\
\text { fMRI data: brain }\end{array}$ & $\begin{array}{l}O=A D \\
O>A D\end{array}$ \\
\hline
\end{tabular}




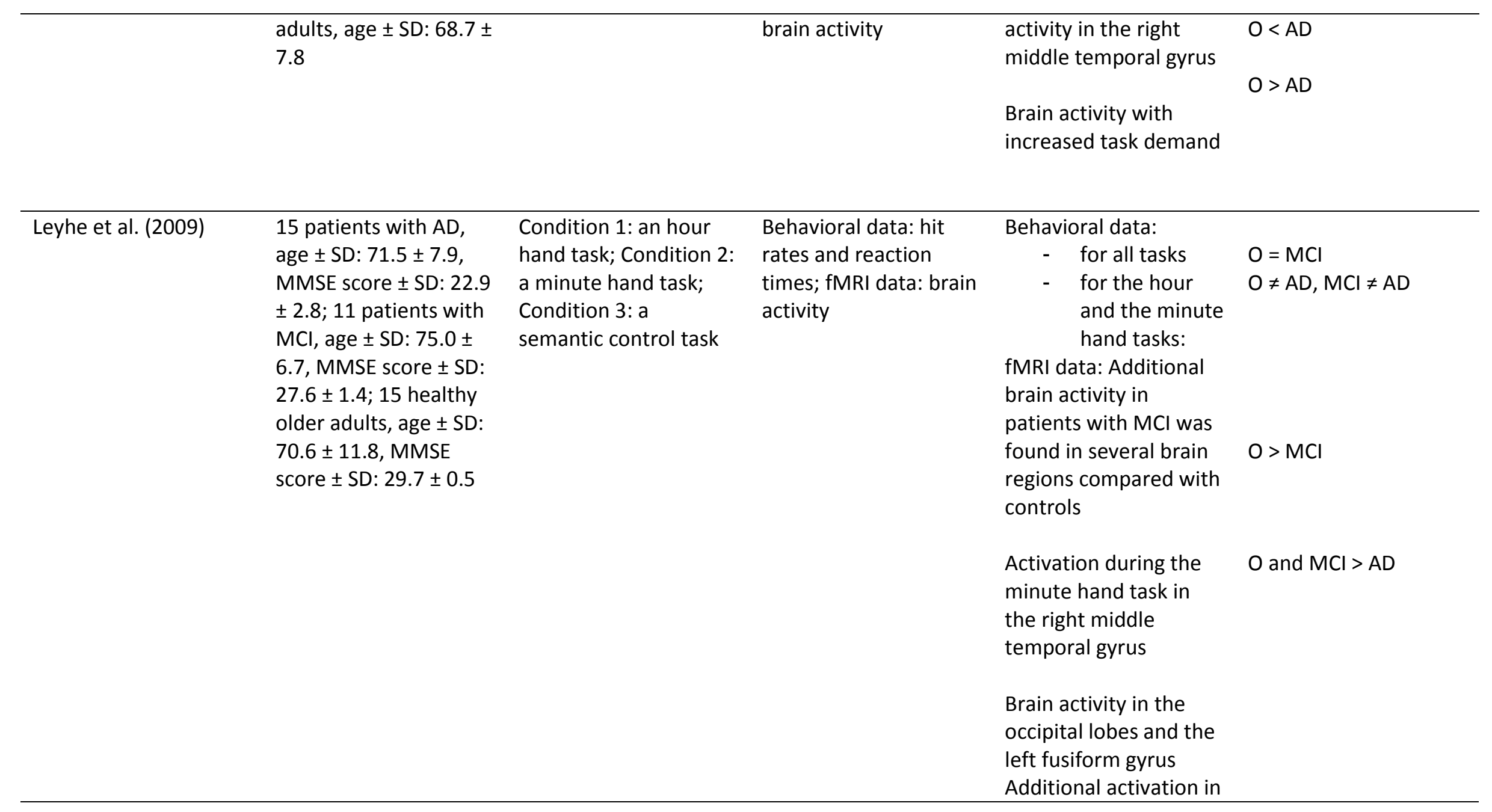




\begin{tabular}{|c|c|c|c|c|c|}
\hline & & & & $\begin{array}{l}\text { the precuneus in } \\
\text { patients with } A D\end{array}$ & \\
\hline Saur et al. (2010) & $\begin{array}{l}12 \text { patients with } A D \text {, } \\
\text { age } \pm \text { SD: } 71.0 \pm 5.8, \\
\text { MMSE: } 29.6 \pm 3.0 ; 10 \\
\text { patients with } \mathrm{MCl} \text {, age } \\
\pm \text { SD: } 73.9 \pm 5.8 \\
\text { MMSE: } 27.8 \pm 1.3 ; 12 \\
\text { healthy older adult, } \\
\text { age } \pm \text { SD: } 70.0 \pm 5.5 \\
\text { MMSE: } 29.6 \pm 0.5\end{array}$ & $\begin{array}{l}\text { Clock reading task and } \\
\text { a spatial control task }\end{array}$ & $\begin{array}{l}\text { Behavioral data: } \\
\text { correct answers and } \\
\text { RT; MRI data: } \\
\text { parameter estimates } \\
\text { of task-related brain } \\
\text { activity }\end{array}$ & $\begin{array}{l}\text { Behavioral data for } \\
\text { both task } \\
\text { Correct answers } \\
\text { RT } \\
\text { fMRI data: } \\
\text { During the spatial } \\
\text { control task, brain } \\
\text { activity in the left } \\
\text { fusiform, the left } \\
\text { lingual and right } \\
\text { inferior temporal gyrus } \\
\text { Correlation between } \\
\text { brain activity and } \\
\text { cognitive state in } \\
\text { several brain regions, } \\
\text { including the lingual } \\
\text { gyrus, cuneus and } \\
\text { precuneus for both } \\
\text { experimental tasks }\end{array}$ & $\begin{array}{l}O \text { and } M C l>A D \\
O<A D\end{array}$ \\
\hline $\begin{array}{l}\text { Sole-Palludes et al. } \\
\text { (2009) }\end{array}$ & $\begin{array}{l}16 \text { patients with mild } \\
\text { AD, age } \pm \text { SD: } 76.5 \pm \\
5.8, \text { MMSE } \pm \text { SD: } 21.7 \pm \\
4.0 ; 12 \text { patients with } \\
\text { aMCl, age } \pm \text { SD: } 74.3 \pm\end{array}$ & $\begin{array}{l}\text { Visual memory } \\
\text { encoding task }\end{array}$ & $\begin{array}{l}\text { Behavioral data: score; } \\
\text { Brain volume: } \\
\text { structural MRI; Brain } \\
\text { activity: fMRI }\end{array}$ & $\begin{array}{l}\text { Behavioral data: } \\
\text { Score } \\
\text { fMRI data: among } \\
\text { healthy older adults, }\end{array}$ & $\begin{array}{l}\mathrm{C}>\mathrm{MCl} ; \mathrm{C}>\mathrm{AD} ; \mathrm{MCl}> \\
\mathrm{AD}\end{array}$ \\
\hline
\end{tabular}


6.2, MMSE \pm SD: $25.8 \pm$

2.2; 16 healthy older

adults, age \pm SD: $73.3 \pm$

4.9, MMSE \pm SD: $27.8 \pm$

0.9 higher cognitive

reserve was related to

larger brain volume

and reduced activity in

several cortical and

subcortical regions

during cognitive

processing.

In patients with $\mathrm{MC}$

and $A D$, higher

cognitive reserve was

related to reduced

brain volumes

In patients with $\mathrm{MCl}$,

no significant

correlation between

cognitive reserve and

brain activity

In patients with $A D$,

higher cognitive

reserve was related to

increased brain

function in the right

anterior cingulate and

lingual gyri 


\begin{tabular}{|c|c|c|c|c|c|}
\hline \multicolumn{6}{|l|}{ PET measures } \\
\hline Gronholm et al. (2007) & $\begin{array}{l}10 \text { patients with aMCl, } \\
\text { age } \pm \text { SD: } 68.6 \pm 8.6, \\
\text { MMSE score } \pm \text { SD: } 27.3 \\
\pm 1.5 ; 10 \text { healthy older } \\
\text { adults, age } \pm \text { SD: } 65.5 \pm \\
6.9, \text { MMSE score } \pm \text { SD: } \\
29.0 \pm 0.7\end{array}$ & Naming test & $\begin{array}{l}\text { Behavioral data: } \\
\text { performance; PET } \\
\text { data: relative changes } \\
\text { in rCBF between the } \\
\text { experimental } \\
\text { conditions }\end{array}$ & $\begin{array}{l}\text { Behavioral data: } \\
\text { Performance } \\
\text { PET data: rCBF in the } \\
\text { anterior cingulate }\end{array}$ & $\mathrm{O}>\mathrm{MCl}$ \\
\hline \multicolumn{6}{|l|}{ Pupil measures } \\
\hline Dragan et al. (2017) & $\begin{array}{l}9 \text { patients with } \\
\text { probable early AD, age } \\
\pm \text { SD: } 69.1 \pm 7.8 \text {, } \\
\text { MOCA: score }<25 ; 8 \\
\text { older adults at risk for } \\
\mathrm{MCl} \text {, age: } 69, \text { MOCA: } \\
23.1 ; 10 \text { healthy older } \\
\text { adults, age: } 66.4 \text {, } \\
\text { MOCA: } 28.1\end{array}$ & $\begin{array}{l}\text { Condition 1: Flicker } \\
\text { change detection task } \\
\text { Condition 2: } \\
\text { Target detection task }\end{array}$ & $\begin{array}{l}\text { Eye data: } \\
\text { Visual search: } \\
\text { Average repeated } \\
\text { entropy, fixation times } \\
\text { and location, number } \\
\text { of fixations, scene } \\
\text { old/new judgments } \\
\text { search times } \\
\text { Pupil data: response } \\
\text { velocity : change in } \\
\text { pupil size due to } \\
\text { stimulus onset }\end{array}$ & $\begin{array}{l}\text { Condition } 1 \\
\text { Visual search: } \\
\text { Entropy from center of } \\
\text { movement } \\
\text { Fixation durations in } \\
\text { repeated trials } \\
\text { Number of fixations } \\
\text { Search times in } \\
\text { repeated trials } \\
\text { Pupil data: } \\
\text { Change in pupil size } \\
\text { Condition } 2 \\
\text { Visual search: } \\
\text { Search times in } \\
\text { repeated trials } \\
\text { Pupil data: }\end{array}$ & $\begin{array}{l}\mathrm{O}<\mathrm{AD} ; \mathrm{MCl}<\mathrm{AD} \\
0<\mathrm{MCl} ; \mathrm{O}<\mathrm{AD} \\
\mathrm{O}<\mathrm{AD} ; \mathrm{MCl}<\mathrm{AD} \\
\mathrm{O}<\mathrm{AD} . \mathrm{MCl}<\mathrm{AD} \\
\mathrm{O}>\mathrm{AD} ; \mathrm{MCl}>\mathrm{AD}\end{array}$ \\
\hline
\end{tabular}


Abbreviations: ADAS-Cog, the cognitive subscale of the Alzheimer's disease assessment scale; aMCI, amnestic mild cognitive impairment; BRF: Background Rhythm Frequency; DPBRF: Dominant Posterior Background Rhythm Frequency; DLPFC, dorsolateral prefrontal cortex; EC: Eigenvector centrality; ERP, Event Related Potential; IPL, Inferior parietal lobule; SSR, Steady state response; NART: National Adult Reading Test; COWAT, Controlled Oral Word Association Test; D: Dementia; EEG: Electroencephalography; MCI: Mild Cognitive Impairment; NCl: No Cognitive Impairment, MMSE: Mini Mental State Examination; NS: Not significant; PD: Parkinson's Disease; PET: Positron Emission Tomography; rCBF: regional cerebral flow; RT: Response Times, SD: Standard Deviation; SE: Standard Error; WCST, Wisconsin Card Sorting Test

aonly data regarding patients with $A D$ and healthy older adults are displayed in this table

${ }^{1} \mathrm{O}=\mathrm{MCl} / \mathrm{AD}$ : no significant differences in behavioral or physiological measures between healthy older adults and patients with mild cognitive impairment/ patients with Alzheimer's disease compared to healthy older adults

$\mathrm{O}>\mathrm{MCl} / \mathrm{AD}$ : significant decrease in behavioral or physiological measures in patients with mild cognitive impairment/ patients with Alzheimer's disease compared to healthy older adults

$\mathrm{O}<\mathrm{MCl} / \mathrm{AD}$ : significant increase in behavioral or physiological measures in patients with mild cognitive impairment/ patients with Alzheimer's disease compared to healthy older adults

${ }^{2}$ low = high: no significant differences in behavioral or physiological measures between the high and low demand conditions

* tendancy to be significant 